\title{
Management Accounting Systems: An organizational competitive performance perspective
}

\section{Elsa Pedroso}

Assistant Professor, University of Coimbra, Centre for Business and Economics Research (CeBER), Faculty of Economics.

Email: elsa.pedroso@fe.uc.pt

\section{Carlos F. Gomes}

Associate Professor, University of Coimbra, Centre for Business and Economics Research (CeBER), Faculty of Economics.

Email: $\underline{\text { cfgomes@fe.uc.pt }}$

This is a pre-copyedited version of an article published in the Benchmarking: An

International Journal. The final version of this article is available online at

This manuscript version is made available under the Creative Commons Attribution Non-commercial International Licence 4.0 (CC BY-NC 4.0). Reuse is allowed in accordance with the terms outlined by this license.

Citation: Pedroso, Elsa and Gomes, Carlos F. (2020), "Management Accounting Systems: An organizational competitive performance perspective", Benchmarking: An International Journal, https://doi.org/10.1108/BIJ-122019-0547. 


\section{Management Accounting Systems: An organizational competitive performance perspective}

\section{STRUCTURED ABSTRACT}

Purpose - The purpose of this paper is to explore the impact of the characteristics and roles of management accounting systems (MAS) on today's business organizations and their management, systems, procedures, people, performance, and competitive environments.

Design/methodology/approach - A survey-based methodology was utilized in this research to gather organizational information relevant to the different facets of the MAS and their operational and strategic practices impact on organizations operating under increasingly uncertain and competitive environments. A structural equation modeling approach was utilized to uncover relevant relationships and associations among relevant variables.

Findings - The findings of this exploratory research revealed a direct influence of MAS on the managerial and organizational performance through the managers' performance. The results also suggest that MAS is directly influenced by users' training, and satisfaction, task uncertainty, and decentralization of decisions. It was also indirectly influenced by top management support. In addition, the findings also revealed a direct influence of the decentralization of decisions on the managers' and on organizational performance.

Research limitations/implications - While this study addressed important issues that have practical management value, it is limited to a sample from one country. Future studies in different businesses and cultural settings are needed to enhance the theoretical and practical contributions of the findings and conclusions of this study.

Practical implications - The issues explored in this study are very much relevant to the utilization and design of MAS and their increasing tactical and strategic roles in the management of today's business organizations. The findings of this study have relevant practical value for managers as they attempt to cope with increasingly competitive environments through the deployment of their existing capabilities and best practices. In this context, the accounting management system has practical utilities that facilitate the control and management of the operations and strategies of the organization.

Originality/value - This research offers practicing management an integrated approach, as they aspire to utilize their organizational MAS to increase the efficiency and effectiveness of their organizations. Integrating the different aspects of management accounting information systems, given their impact on the different aspects of the organization, is needed for the establishment of theoretical research models aiming at the enhancement of the competitive performance of today's organizations. This study also offers to executives of SMEs a new multidimensional instrument for assessing the effectiveness of their management information systems, which can help to improve their benchmarking processes.

\section{Paper type: Research paper}

Keywords - Management accounting systems, performance management, Information characteristics, benchmarking, Small and medium enterprises, MAS. 


\section{Management Accounting Systems: An organizational competitive performance perspective}

\section{Introduction}

The theory, practice, and strategy associated with benchmarking have evolved significantly over the last several years. In the process, the focus of benchmarking shifted from merely searching for the best practice associated with carrying out a given activity to broader focuses, which is on a total and systematic philosophy aimed at improving the competitive position of the organization in the business market place (Yasin, 2002; Hong et al., 2012; de Castro and Frazzon, 2017).

The early focus of benchmarking, which was activity-based, was consistent with the closed system view of the organization. As such, the benchmarking was designed to enhance operational efficiency. However, the broader-based approach of benchmarking focused on a continuous focus on the organization as an open system interacting with suppliers, customers, employers, shareholders, and the environment of the organization. This open system approach at the benchmarking effort requires a well-designed strategy, which promotes effectiveness without compromising efficiency and customer orientation. Such an approach integrates best practices related to people, operations, processes, and systems in order to gain and maintain a strategic competitive advantage. Therefore, this approach pays special attention to systems within the organization, which target the different facets of performance both at the operational as well at the strategic levels. The management accounting system is a clear example of such an organizational system. This system tracks the efficiency of internal operational and related tasks, as well as the effectiveness of the organizations in a 
competitive environment. Therefore, learning about the interactions with this system are relevant to both internal as well as external benchmarking efforts.

Organizations competing in the global market face major challenges. Such challenges are related to the efficient use of their resources; in addition, these challenges are related to the uncertainty of their external environment. This uncertainty becomes much more challenging for SMEs (Raymond et al., 2019).

In highly competitive and uncertain markets, business organizations need effective management control systems to implement new strategies (Wynn-Williams, 2005) successfully. Therefore, information has become one of the most valuable organizational resources, and its sharing across the enterprise has become an important performance driver (Evans, 2007). The analysis of such information will enable managers to identify which actions are most appropriate to their objectives, to outline a plan to achieve these objectives, to follow up on the implementation, and to help them in solving problems (Mendoza and Bescos, 2001; Soobaroyen and Poorundersing, 2008). This information has the potential to improve organizational performance (Chenhall, 2003). In this context, technologies and information systems are essential tools to support the managers of these companies in decision-making processes (Marchand and Raymond, 2018).

Recently there has been a growing importance of the role of emerging information technologies, as they impact the organizational nature of accounting systems (Chiu et al., 2019). The emergence of new challenges brought about new information technologies has significantly influenced the MAS. This interim has caused new developments in accounting practices over the past few years (Kocsis, 2019). 
Specifically, these developments have posed new challenges to accountants. Nowadays, accountants not only have to assume new roles in the management of their organizations but also, they have to be aware of new practices and procedures dictated by the evolving information technologies and systems and their impact on their MAS (Appelbaum et al., 2017; Oesterreich et al., 2019).

In these new business environments, companies' competitiveness is challenged daily by their competitors, and their workers are exposed to new performance-enhancing challenges, for which they need to be creative and innovative. As such, it seems to exist an apparent contradiction between the current business environment that requires innovation and creativity, accompanied by free and open communication, and the coordination and control function that is a traditional feature of management accounting (Pärl, 2014). However, contrary to the results obtained previously by the management accounting literature, workers can achieve increasingly demanding goals, being creative in innovative processes (Pfister and Lukka, 2019). Companies are now using innovative information management systems, as is the case with business intelligence, to enhance the use of management accounting practices (Peters, Wieder and Sutton, 2018). Management accounting is also called upon to follow society's challenges, contributing to the assessment of companies' environmental performance (Zyznarska-Dworczak, 2018).

Thus, it seems that we are witnessing a paradigm shift, in which management accounting has moved away from its traditional approach, which encourages command and control mechanisms and raises barriers to innovation (Davila, Foster and Oyon, 2009). It has now become a management instrument to assist company managers in 
the continuous process of organizational change (Aaltola, 2019), with different approaches for small, medium, and large companies (Pelz, 2019).

Given this new accounting environment, the role, scope, and contribution to organizational performance by the accounting systems have to be reexamined within eye towered dynamic interactions and relevant integration of practices and the role of the human element in this entire process.

Several approaches have been suggested in the literature to evaluate the effectiveness of MAS and their interactions with other factors in the business environment. The information characteristics of the MAS were found to be one of the topics of greatest interest in the literature. However, based on the literature reviewed, it seems that no multidimensional construct that can measure the characteristics of the information provided by MAS in a comprehensive way is available. In addition, no integrated research model with a multidimensional perspective of external and internal factors influencing MAS was found. The literature appears to emphasize single relationships and to test hypotheses accordingly (e.g., Pondeville, Swaen and De Rongé, 2013; Nguyen et al., 2017; Ghorbel, 2019). Motivated by the need to understand the new roles, challenges, and realities imposed on the organization, its managers and employees, the research questions below are in order. It is to be noted that the motivating factor behind these questions is the apparent research gap in this important area.

I. To what extent the information provided by a multidimensional MAS tend to influence the managers' performance and the organizational performance of SMEs? 
II. What are the factors of the SME business environment that may influence the utilization of the multidimensional MAS?

III. Which of these factors could also influence the managers' performance and the organizational performance of SMEs?

With the above in mind, the objective of this study is to analyze the potential relationships among the information provided by multidimensional MAS, and the performance of the SMEs. In the process, factors that contribute to the effective utilization of such information are explored.

Based on an extensive literature review, to answer the research questions presented above, and to achieve the proposed objective, a research model was developed to analyze the contingency factors of the MAS along with their influence on performance. A new instrument, which facilitates the evaluation of MAS based on a multidimensional and an integrating approach in relation to the information they provide, is presented. Despite the importance of the relationships tested, the main contribution of this study is the model representing the comprehensive approach pertaining to the organizational role of the MAS. The research model proposed by this study has important theoretical implications relevant to the integration of the relationships studied, as well as practical implications. As such, findings of this study have direct benchmarking implications both internally to the organization and externally to its partners.

The data required for the utilization of this model was obtained by applying a survey to a representative sample of Portuguese SMEs. The choice of companies with these characteristics is based on the following two reasons: 1 ) the economic and social 
relevance of this segment of enterprises to the national business environment; 2 ) the existence of a small number of empirical studies related to the MAS in this business context.

This article is divided into eight sections. Following this introduction, section two includes the background and theoretical development of the research model (Figure 1), along with the relevant hypotheses. The next section describes the sample and data collection, along with the research instrument and variables measurement. In section four, the results are presented. Section five presents the discussion, which includes implications for theory and for practice. The next sections present conclusions, limitations, and future research.

\section{Background and theoretical model development}

\subsection{Background}

For the purpose of this study, an extensive literature review of studies published over the last twenty years, in major journals related to the topic, was carried out. Whenever necessary, previous publications were analyzed to help to understand the evolution of the concepts related to management accounting. The literature review helped to verify that research in management accounting has followed several directions related to different subjects of this research area. One of the most frequently studied subjects is the characteristics of the information provided by the MAS. In this context, several gaps have been identified regarding the approaches used.

Management accounting is transversal to all types of organizations. These cross-section characteristics can be verified by the various industries studied in the literature, 
including food and beverage industries (Abdel-Kader and Luther, 2008), hospitals (Hammad, Jusoh and Ghozali, 2013), manufacturing industries (Hariyati, Tjahjadi and Soewarno, 2019), and financial organizations (Ghasemi et al., 2019). There is also some cross-cutting about the size of the organizations studied, including large companies (Cadez and Guilding, 2008), medium size (Williams and Seaman, 2002), small size (Halabi, Barrett and Dyt, 2010), and micro size (Alattar, Kouhy and Innes, 2009).

Management accounting systems provide information to assist managers in planning and control activities and to help them in solving problems (Soobaroyen and Poorundersing, 2008). They provide information for performance evaluation, including financial measures such as return on assets and return on investment, and nonfinancial measures such as customer satisfaction and product quality (Choe, 2004). According to Chenhall and Morris (1986), this information should be evaluated for the perceived utility of several characteristics that can be associated with it, namely the scope (external, nonfinancial, and future-oriented information), the timeliness (frequency and speed of reporting), the level of aggregation (aggregated information by time period and/or functional area, and analytical information in formats appropriate to decision models), and the level of integration (information on precise targets for the various activities, and their interrelationship within organizational subunits, along with reports on intra-sub-unit interactions).

Many studies related to the influence of the business environment on MAS and performance can be found. Regarding the organizational context, several factors were found, including user satisfaction with the MAS, user training, the support of top managers, task uncertainty, decentralization of decision-making power, and 
accountant participation in the strategic decisions. Regarding the influence of the competitive environment on the information of MAS, the most used variable in literature has been the uncertainty of the external environment. The most frequently dependent variables used in the literature reviewed are the managerial performance (e.g., Chong, 2004; Agbejule, 2005; Sharma, Jones and Ratnatunga, 2006; Soobaroyen and Poorundersing, 2008; Etemadi et al., 2009; Hammad, Jusoh and Ghozali, 2013; Ghasemi et al., 2016, 2019; Nguyen et al., 2017) and the organizational performance (Cadez and Guilding, 2008; Hoque, 2011; Tuanmat and Smith, 2011; Ismail, Isa and Mia, 2018).

For the purpose of this study, Figure 1 is used to present the proposed research model. The model was conceptualized based on the variables extracted from the literature and the feedback obtained from experts in this research field.

\section{[Insert Figure 1]}

This research model was developed considering the contingency theory and the resource-based view (RBV) theory. Contingency theory suggests that the efficiency of an organization depends on the adequacy of its internal structure to the contingencies of its external environment (Walker et al., 2015). Research in management accounting is necessarily contingent in that it seeks to find out which techniques are most appropriate for particular organizations in specific circumstances (Otley, 2016). RBV theory suggests that the resources and competencies of the company affect its competitive position and its organizational performance (Walker et al., 2015). The application of this theory to the information systems allows understanding how the resources and capacities of these systems affect the performance of the companies. 
Based on this theory, a company's performance can be explained by the degree to which it uses the information to support and improve its core competencies (Ravichandran and Lertwongsatien, 2005). In this context, the hypotheses to be examined in the current study will be presented in the next sections.

\subsection{The influence of organizational factors on the MAS}

\subsubsection{Top management support}

Top managers are key resources of corporate management. Therefore, they are very important in achieving operational and strategic objectives. In this context, their support is crucial for the implementation and effective utilization of management decision-aiding instruments. Support from top managers relates to the degree of aid given by senior-level managers to the development, implementation, and use of new techniques, methods, and processes in an organization (Shields, 1995; Foster and Swenson, 1997; Krumwiede, 1998; Krumwiede, Suessmair and MacDonald, 2008). This support is provided through an open and active promotion by these managers in financial or spiritual terms (Fong and Quaddus, 2010).

Several authors have investigated the influence of top management support in the implementation, development, and use of new techniques and methods in management accounting and information systems (e.g., Krumwiede, Suessmair and MacDonald, 2008; Fong and Quaddus, 2010; Tontiset and Ussahawanitchakit, 2010; AlSayed and Dugdale, 2016). In this context, the support from top managers was found to be positively associated with the adoption, implementation, and utilization phases of innovations techniques in companies (Al-Sayed and Dugdale, 2016). 
The more support from top managers, the more likely management accounting is to be successfully implemented, including more accurate production cost calculations, more efficient inventory valuation, and more efficient financial reporting (Tontiset and Ussahawanitchakit, 2010). Increasing support from top managers should also increase the commitment of managers not directly involved in management accounting. This commitment results from these managers being encouraged to pay more attention and use more frequently the information provided by MAS in their decision-making processes. Strong support from top managers will also result in increased user training for the development and use of management accounting, as well as improved accuracy of the information provided (Krumwiede, Suessmair and MacDonald, 2008). In this context, it is also expected that an increase in top management support can increase user satisfaction (Fong and Quaddus, 2010). Based on literature cited above pertaining to the role of top management and the importance of is support the hypotheses below are formulated.

Hypothesis 1a: The support of top managers positively influences the use of information provided by MAS.

Hypothesis 1b: The support of top managers positively influences the training of MAS users.

Hypothesis 1c: The support of top managers positively influences user satisfaction with information provided by MAS.

\subsubsection{Training of MAS users}

Organizations usually face several risks in the implementation and effective utilization of information technology and systems. The most difficult of these risks which must be taken into consideration are related to the skills of users of these systems, like the 
inability of companies to recruit skilled people (Suwardy et al., 2003), or the difficulty in ensuring effective training for users of these systems (Garg and Khurana, 2017). As such, the training of users needs to be emphasized, as it leads to benefits in the implementation and utilization of information systems. It also aims to facilitate a better understanding of the type of information required for the analysis of activities and their performance measures (Chenhall and Langfield-Smith, 1999). The training of users consists of providing training courses in the work context to assist in the implementation and use of information systems (Fong and Quaddus, 2010).

The purpose of training users is to learn how these systems can help them run their businesses. It is logical to assume that more training would give users a better understanding of the design, implementation, and use of the system. This should increase utilization and provide more accurate information (Krumwiede, Suessmair and MacDonald, 2008). It is also acceptable to speculate that lack of user training will lead to dissatisfaction. Therefore, the increase in this training may lead to the enhancement of the users' satisfaction pertaining to the use of information provided by the information systems.

Based on the above discussion, the following hypotheses are presented:

Hypothesis 2a: The training of MAS users positively influences the use of the information provided by these systems.

Hypothesis $2 \mathrm{~b}$ : The training of MAS users positively influences user satisfaction with the information provided by these systems.

\subsubsection{User satisfaction with information provided by the MAS}


The satisfaction of information systems users is related to several factors, including the relevance of the information provided by these systems (Pizzini, 2006), the quality of that information (Rai, Lang and Welker, 2002; Cohen and Kaimenaki, 2011), and the quality of the systems (Rai, Lang and Welker, 2002). The relevance of the information can be measured by comparing managers' perceived information needs and the information effectively provided by the information systems (Pizzini, 2006).

The quality of the information expresses the perceived utility by its users regarding the utilization of information in decision-making, its compatibility with users' needs, relevance, timeliness, reliability, and accuracy of information (Cohen and Kaimenaki, 2011). The quality of the information can also be defined by the intensity with which the information provided has the content, the precision, and the format required by the user (Rai, Lang and Welker, 2002). The quality of the information system can be defined by the ease of use level. Rai et al. (2002) evaluated user satisfaction directly through the level of satisfaction with the information system, but also indirectly through the quality of the information and the quality of the system. Both the quality of information and the quality of the system positively influence user satisfaction. In turn, user satisfaction has a positive effect on the degree of user dependence on the system.

Regarding users' satisfaction with management accounting, the greater the satisfaction with the information provided by the MAS, the greater the use that will make of that information (Fong and Quaddus, 2010; Macinati and Anessi-Pessina, 2014). As such, the following hypothesis is formulated: 
Hypothesis 3: User satisfaction with information provided by MAS positively influences the use of this information.

\subsubsection{Task uncertainty}

The task uncertainty can be defined as the difference between the amount of information required to perform a given task and the amount of information already existing (Galbraith, 1973, 1977). This uncertainty can become a barrier to innovation in highly competitive markets (Bartnik and Park, 2018).

When the degree of uncertainty in the task is low, the need for managers to use broader scope information for decision-making decreases because the interpretation of the variables for performing the task is relatively more simple. A higher degree of task uncertainty requires managers to demand a broader scope of information to address the complexity of these variables. Broader information scope can help managers reduce uncertainty and make better decisions, which will translate into improved performance (Chong, 2004).

When facing high task uncertainty, there may not be enough information to complete these tasks. In this case, the MAS can play a relevant role in filling this gap by providing information that helps managers better understand the problems, and therefore, make better decisions (Soobaroyen and Poorundersing, 2008). As such, it seems plausible that a positive relationship between the degree of task uncertainty and information provided by the MAS may exist. However, Soobaroyen and Poorundersing (2008) found this relationship not significant for scope, timeliness, and integration dimensions of MAS. Regarding the direct influence of the task uncertainty on the performance of the managers, it was also not considered significant in the literature (Chong, 2004; 
Soobaroyen and Poorundersing, 2008). As such, the following hypotheses are formulated:

Hypothesis 4a: The uncertainty in tasks positively influences the use of the information provided by MAS.

Hypothesis $4 \mathrm{~b}$ : The uncertainty in tasks negatively influences the performance of the managers.

\subsubsection{Decentralization of decisions}

Decentralization of decision-making power can be defined as the level of autonomy delegated to managers, giving them greater responsibility for planning and controlling activities (Waterhouse and Tiessen, 1978), which can be seen as a process of empowerment of these managers (Conger and Kanungo, 1988). This is an organizational issue that large companies face to monitor and control their business units around the world (Aoki and Miyajima, 2012). However, SMEs face a similar problem regarding their departments and functions.

Based on the literature reviewed, we found several studies that investigated the effects of centralization/decentralization of decision-making power in management accounting (e.g., Chenhall and Morris, 1986; Abdel-Kader and Luther, 2008; Soobaroyen and Poorundersing, 2008; Hoque, 2011; Erserim, 2012; Hammad, Jusoh and Ghozali, 2013; Ern, Abdullah and Yau, 2016).

Regarding the relationship between decentralization and the use of information provided by MAS, the literature suggests the existence of a positive relationship between decentralization and the use of timely, aggregated and integrated information by managers (Hammad, Jusoh and Ghozali, 2013). 
The effect of decentralization of decision-making power on managers' performance and on organizational performance, has also been studied in the literature. Soobaroyen and Poorundersing (2008) concluded that the decentralization of decision-making power has no direct influence on the performance of managers. However, there is an indirect influence exerted through the information provided by MAS. In turn, Hoque (2011) concluded that decentralization is positively and directly associated with organizational performance.

The decentralization of the company's decision-making power has a beneficial effect on the quality and sophistication of the information provided by the MAS at a functional level, which in turn has a combined positive effect on the performance of managers (Soobaroyen and Poorundersing, 2008). As a result of the above discussion, the following hypotheses are formulated:

Hypothesis 5a: Decentralization of decision-making power positively influences the use of information provided by MAS.

Hypothesis 5b: Decentralization of decision-making power positively influences the performance of managers.

Hypothesis 5c: Decentralization of decision-making power positively influences organizational performance.

\subsubsection{Accountant participation in strategic decisions}

The increasing use of multi-dimensional performance evaluation systems that include financial and non-financial indicators has brought major challenges for accountants (Rickards, 2003). However, they seem to be responding positively to these challenges (Guven-Uslu, 2005). The participation of the accountant in the strategic decisionmaking process is measured by his degree of involvement in the formulation and the 
implementation of the company's strategy (Wooldridge and Floyd, 1990; Cadez and Guilding, 2008, 2012). It seems that companies with greater participation of the accountant in the strategic decision process are those that follow a more analytical strategy, those with more propensity to look for new products and market opportunities, and those that are more oriented to the domestic market (Cadez and Guilding, 2012).

Cadez and Guilding (2008) tested the positive influence of the accountant's participation in the decision-making process on the use of strategic management accounting and on organizational performance. They found the direct and positive influence on the use of strategic management accounting, but not the direct effect on organizational performance. However, they found an indirect effect of the accountant participation in the decision process on the organizational performance, exercised through the utilization of strategic management accounting. As a result of the above discussion, the following hypotheses are formulated:

Hypothesis 6a: The participation of the Accountant in the strategic decision-making processes positively influences the use of the information provided by MAS.

Hypothesis 6b: The participation of the Accountant in the strategic decision-making processes positively influences organizational performance.

\subsection{The influence of the competitive environment}

The uncertainty of the external environment has been identified as a factor that hinders management activities, particularly the planning and control activities (Chenhall and Morris, 1986). Increasing market uncertainty often creates strategic and operational 
alignment reactions from companies that wish to remain competitive (Guven-Uslu, 2005), which are reflected in their monitoring and management control instruments, like MAS.

The literature presents several studies that investigate the relationships of external competitive environment uncertainty with management accounting, either with the management accounting practices (Abdel-Kader and Luther, 2008; Erserim, 2012) or with the characteristics of the information of MAS (Chenhall and Morris, 1986; Chiou, 2011; Hammad, Jusoh and Ghozali, 2013; Ghorbel, 2019). As for the information provided by MAS, only a few authors have investigated the relationship of external environment uncertainty with its four dimensions (e.g., Chenhall and Morris, 1986; Chiou, 2011; Pondeville et al., 2013). Although the uncertainty of the external environment was expected to positively influence the use of the MAS information in its different dimensions, not all the studies presented the same findings.

Hammad et al. (2013) evaluated the influence of the uncertainty of the external environment on the use of MAS information and found that it has a negative relation with the dimensions of scope, timeliness, and aggregation. This study did not demonstrate statistical significance of the relationship between the uncertainty of the external environment and the level of integration of the information provided by MAS. Similar results were found by Pondeville et al. (2013).

The results of the studies above do not corroborate the findings of Chenhall and Morris (1986), which revealed a positive relationship between the uncertainty of the external environment and the scope and timeliness of the information, as well as the lack of significance with the level of the aggregation of the information. However, they confirm 
the existence of an indirect effect of the external environment on the level of the aggregation of information, through the decentralization of decision-making power. This indirect effect was not confirmed for the scope of the information.

As for the direct effects, contrary to the findings of Chenhall and Morris (1986), Chiou (2011) concluded that the existence of a direct and positive relationship between the uncertainty of the external environment and the scope and timeliness dimensions was not statistically significant. However, they found a positive relationship between the external uncertainty and the level of aggregation of information provided by MAS.

More recently, Ghorbel (2019) concluded that the environment uncertainty related to the availability of raw materials, commodity prices, and government regulations does not seem to influence the utilization of broadly, timely and aggregated information. However, when environment uncertainty is related to the quantity and quality of the market demand, it has a positive effect on the scope and timeliness dimensions.

The uncertainty of the external environment seems to be associated with the preference for timeliness and broad scope information (Chenhall and Morris, 1986). In highly competitive markets, the broad scope of information becomes essential for assessing demand and action of the competition, and timely information helps to reduce uncertainty (Agbejule, 2005). As a result of the above discussion, the following hypotheses are formulated:

Hypothesis 7a: The uncertainty of the competitive environment positively influences the decentralization of decision-making power.

Hypothesis 7b: The uncertainty of the competitive environment positively influences the use of the information provided by MAS.

Hypothesis 7c: The uncertainty of the competitive environment negatively influences the performance of managers. 
Hypothesis 7d: The uncertainty of the competitive environment negatively influences organizational performance.

\subsection{The influence of MAS utilization on performance}

It is logical to assume that information is an important resource with intangible characteristics that can generate a positive competitive advantage for companies that use it effectively. In general, information can be used in a variety of ways, whether through decision support for managers or as an important driver of innovation to create competitiveness (Huang, Lai and Lin, 2011). In any case, the organization's performance can be explained by the degree of use of information to support and improve its core competencies (Ravichandran and Lertwongsatien, 2005).

One of the most cited approaches to access the MAS characteristics was presented by Chenhall and Morris (1986). These include the four following key information dimensions: I) scope; ii) timeliness; iii) level of aggregation, and iv) level of integration.

The scope characteristic is related to the focus, quantification, and time horizon of the information (Chenhall and Morris, 1986; Hammad, Jusoh and Ghozali, 2013). The information provided by the MAS may be of a narrower or a broader scope (Soobaroyen and Poorundersing, 2008). The scope range is dependent on whether the information is internal or external, financial or non-financial, historical, or futureoriented (Hammad, Jusoh and Ghozali, 2013). As such, the information of narrower scope has been associated with the traditional accounting systems that provide internal, financial and historical information (Chenhall and Morris, 1986; Fong and Quaddus, 2010). The broader scope of information is related to the external 
environment and maybe economic or non-economic (Chenhall and Morris, 1986; Sharma, Jones and Ratnatunga, 2006).

The timeliness characteristic relates to the frequency with which the information is reported and the speed with which it occurs (Fong and Quaddus, 2010). According to Hammad et al. (2013), timeliness of information concerns the readiness with which information is made available upon request. For Soobaroyen and Poorundersing (2008), this dimension is related to the slow or rapid response to requests for standardized or personalized information. Timely information enhances the ability of MAS to report on recent events and to provide faster feedback on decisions (Chenhall and Morris, 1986).

The level of aggregation of information consists of the systematization of information by time period, functional areas, or even formats consistent with formal decision models (Chenhall and Morris, 1986; Hammad, Jusoh and Ghozali, 2013). Information aggregated at the functional level provides managers with information on the results of other departments (Fong and Quaddus, 2010).

The level of information integration includes the precise definition of goals for the various activities and their interrelationships within the sub-units, as well as reporting on intra-sub-unit interactions (Chenhall and Morris, 1986; Soobaroyen and Poorundersing, 2008). The level of information integration also deals with data that cross-functional boundaries and helps to coordinate multiple segments within a subunit (Hammad, Jusoh and Ghozali, 2013).

To evaluate the informational characteristics of MAS, Chenhall and Morris (1986) developed four constructs to measure each of these dimensions, which have been used 
individually by several authors (Table 1). Since then, this instrument has also been used to assess the characteristics of other information systems (Pondeville, Swaen and De Rongé, 2013; Esparza-Aguilar, García-Pérez-De-Lema and Duréndez, 2016; Gunarathne and Lee, 2019). However, over the last twenty years, only a few authors have decided to use the four dimensions (e.g., Bouwens and Abernethy, 2000; Naranjo-Gil, 2009; Velez et al., 2015; Ghasemi et al., 2016; Hariyati and Tjahjadi, 2018).

\section{[Insert Table 1]}

Along with the differences in the number of dimensions used in the literature, other differences were found in the structure of the constructs, namely concerning the number of items included in each construct. In the literature, several relationships between the information provided by the MAS and other business variables have been studied. In some studies, information dimensions are used as dependent variables (Chenhall and Morris, 1986; Bouwens and Abernethy, 2000; Chiou, 2011; Ern, Abdullah and Yau, 2016; Ghorbel, 2019), in other studies as independent variables (Chang, Chang and Paper, 2003; Agbejule, 2005; Mollanazari and Abdolkarimi, 2012; Esparza-Aguilar, García-Pérez-De-Lema and Duréndez, 2016), and in some other studies, they are both dependent and independent variables (Soobaroyen and Poorundersing, 2008; Etemadi et al., 2009; Hammad, Jusoh and Ghozali, 2013; Ismail, Isa and Mia, 2018; Ghasemi et al., 2019; Hariyati, Tjahjadi and Soewarno, 2019).

Management accounting systems play a major role in performance measurement, providing information often used as a basis for defining the measures that will allow an effective performance measurement process. This process includes all aspects of the management cycle of a business organization (Agbejule, 2011). Throughout the 
literature review, several studies which evaluated different types of performance were found, including the following performance dimensions: production performance (Choe, 2004); financial performance (Jansen, Van den Bosch and Volberda, 2006; Macinati and Anessi-Pessina, 2014; Hariyati and Tjahjadi, 2018; Hariyati, Tjahjadi and Soewarno, 2019); departmental performance (Williams and Seaman, 2002); the nonfinancial performance of the production (Abdel-Maksoud, 2004; Abdel-Maksoud et al., 2010); managers' performance (Chong, 2004; Agbejule, 2005; Sharma, Jones and Ratnatunga, 2006; Hall, 2008; Soobaroyen and Poorundersing, 2008; Hammad, Jusoh and Ghozali, 2013; Ghasemi et al., 2016, 2019; Nguyen et al., 2017); global performance (Esparza-Aguilar, García-Pérez-De-Lema and Duréndez, 2016); and organizational performance (Mendoza and Bescos, 2001; Ambe and Sartorius, 2002; Cadez and Guilding, 2008, 2012; Krumwiede, Suessmair and MacDonald, 2008; Cleary, 2009; Tontiset and Ussahawanitchakit, 2010; Agbejule, 2011; Tsamenyi, Sahadev and Qiao, 2011; Tuanmat and Smith, 2011; Hoque, 2011; Ismail, Isa and Mia, 2018). In this context, the following hypotheses are presented:

Hypothesis 8a: The use of information provided by MAS positively influences the performance of managers.

Hypothesis $8 \mathrm{~b}$ : The use of information provided by MAS positively influences organizational performance.

Hypothesis 9: The performance of managers positively influences organizational performance. 


\section{Research design}

\subsection{Sample and data collection}

For the purpose of this study, the data was collected through an online survey. Chief Financial Officers (CFOs) of Portuguese small and medium enterprises (SMEs) were invited to participate in the study.

The names and addresses of 1500 SMEs were obtained from Informa DB, which belongs to the Dun and Bradstreet Worldwide Network. All these enterprises were contacted by phone to explain the objective of the research study and to obtain the name of their CFO. Twelve enterprises, despite several attempts, never answered our calls. Ninetythree enterprises declined to collaborate in this research study for several reasons, such as no longer operating and a lack of autonomy to respond to the questionnaire. Therefore, an email explaining the purpose of the research and containing the link to the online survey was sent to 1407 CFOs of Portuguese SMEs. As an incentive to increase CFOs' participation, they were promised a summary of the research findings. A total of 255 usable responses were obtained from CFOs, representing a response rate of 18.12 percent. This response rate cannot be considered high. However, it is consistent with similar studies (Moores and Yuen, 2001; Hall, 2008). Table 2 presents the sample characteristics.

\section{[Insert Table 2 here]}

\subsection{Instrument and variable measurement}

The research instrument used in this study was designed based on an extensive literature review. In the first phase of the questionnaire design, it was translated and 
adapted to the Portuguese business environment. In the second phase, the instrument was submitted to a panel of experts from several organizations. During this phase, particular attention was given to the use of terminology consistent with the background of the survey participants.

The final version of the research instrument contains sixty items representing the observed variables related to the constructs used in the research model presented in Figure 1. All these observed characteristics were measured on a Likert scale with a range of 1 to 7 . The questions and descriptive statistics of the survey answers are presented in Appendix A. All the constructs were derived from previous studies (Table 3).

\section{[Insert Table 3 here]}

\section{Results}

\subsection{The measurement model}

Before proceeding to the exploratory factorial analysis, the response scale of the construct "Task uncertainty" was reversed. After this change, a high (or low) score on items indicates a high (or low) level of task uncertainty, simplifying the interpretation of the results (Chong, 2004).

During the preliminary analysis of the data resulting from the survey, normality assumptions were analyzed. The values of kurtosis and skewness ( see Appendix A) do not exceed indicative limits for the verification of the univariate normality assumption (Curran, West and Finch, 1996). Regarding the Mardia coefficient, although presenting 
a value higher than the advisable limits, it will not be worrisome because the estimation method used is the maximum likelihood, and the assumption of univariate normality was verified. For this reason, no data remedy was applied (Hoyle, 1995; Tabachnick and Fidell, 2007).

The existence of outliers was verified through the square of Mahalanobis distance $\left(D^{2}\right)$. However, no values above the limits suggested by Hair et al. (2014) were found. Therefore, none of the cases were withdrawn.

Common method variance was verified with Harman's single factor test by conducting an exploratory factor analysis (Podsakoff et al., 2003). The unrotated factor solution was analyzed for verifying the number of factors needed to explain the variance of the variables. If the total variance of a single factor is less than $50 \%$, then the data has no issues of common method variance. In this study, the results show that the first factor only accounts for $26.28 \%$ of the total variance, which means that the data has no common method variance issues.

Using the exploratory factorial analysis, the KMO sampling adequacy measure and the Bartlett test, the unidimensionality of the observed variables was verified (Chong, 2004; Soobaroyen and Poorundersing, 2008). At the end of this phase of data analysis, it was decided to eliminate variable TUN02, from the construct task uncertainty, since its loading was less than 0.4 .

Confirmatory factor analysis was then performed, through AMOS 22, using the maximum likelihood method to estimate the results. The initial measurement model presented a moderate adjustment to the sample data $\left(\chi^{2}=2826.99, \mathrm{df}=1603, p\right.$-value $=0.000, \chi^{2} / d f=1.764 ;$ RMSEA $=0.055$, PCLOSE $=0.009, \mathrm{TLI}=0.885, \mathrm{CFI}=0.892, \mathrm{PCFI}=$ 
0.836 , and $M E C V I=12.852)$. All factor loadings are statistically significant ( $p$-value $<0.001$ ) and have standardized estimates above 0.5 . To improve the fit, the model was modified in successive iterations considering the best practices presented in the literature (Hair et al., 2014). In this process, modifications involving correlated error terms were avoided (Anderson and Gerbing, 1988; Hair et al., 2014). Therefore, a few variables were excluded in this process (see Appendix A).

Following the above-mentioned modifications, the new measurement model has significantly improved the quality of its adjustment $\left(\chi^{2}=1882.007, \mathrm{df}=1225, p\right.$-value $=$ 0.000, $\chi^{2} / \mathrm{df}=1.536, \mathrm{RMSEA}=0.046, \mathrm{PCLOSE}=0.95, \mathrm{TLI}=0.924, \mathrm{CFI}=0.929, \mathrm{PCFI}=$ 0.859 , and $M E C V I=8.932)$. The loading factors continue to be all statistically significant ( $p$-value $<0.001$ ) and have standardized estimates above 0.5 . In addition, MECVI for the adjusted measurement model is lower than the initial measurement model (12.852 in the initial model versus 8.932 in the adjusted model), indicating that the adjusted model has better external validity than the initial model.

Regarding the validation of the constructs $C R, A V E$ and Cronbach's alpha presented values above $0.7,0.5$, and 0.7 , respectively (Table 4 ), indicating internal consistency, convergent validity adequacy, and reliability of the model constructs (Hair et al., 2014). It is also verified that the model does not present discriminant validity issues, indicating that the various constructs are different from each other. After the validation of the measurement model, the structural model was analyzed, where the hypotheses presented in our study were tested.

\section{[Insert Table 4]}




\subsection{The structural model}

The structural model (Figure 1) was estimated using the maximum likelihood method. Their estimation resulted in adjustment indexes very similar to those presented by the adjusted measurement model $\left(\chi^{2}=1986.053 ; \mathrm{df}=1244 ; p\right.$-value $=0.000 ; \chi^{2} / \mathrm{df}=1.597 ;$ RMSEA $=0.048 ;$ PCLOSE $=0.736 ; \mathrm{TLI}=0.915 ; \mathrm{CFI}=0.920 ; \mathrm{PCFI}=0.863$ and $\mathrm{MECVI}=$ 9.152). Therefore, it can be considered that the structural model presented an acceptable fit.

Figure 2 and Table 5 present the results of factor loadings and their statistical significance ( $p$-value). These results indicate that our study empirically confirms 13 of the 20 hypotheses tested.

\section{[Insert Table 5]}

[Insert Figure 2]

Although the hypotheses formulated in our study refer only to direct effects between latent variables, indirect effects (Table 6) related to empirically unconfirmed hypotheses (1b, 5a, 6b, 8a, 8b e 9b) were analyzed. For the estimation of the indirect effects, we used the Bootstrapping technique, with a sample of 2000 observations and a confidence interval of $90 \%$.

\section{[Insert Table 6]}

According to the results (Table 5), none of the hypotheses related to accountant participation in the strategic decision were confirmed. As such, there were no indirect effects related to the variables involved in these hypotheses. 
The top managers' support and the competitive environment uncertainty may not directly influence the use of the information provided by MAS (hypotheses $1 \mathrm{a}$ and $7 \mathrm{~b}$, respectively), but they indirectly influence it. The support of top managers indirectly influences the use of the information provided by MAS through its influence on the training of MAS users, and on their satisfaction with the information provided by MAS systems. This result could be explained by the total mediation effect of user training and user satisfaction variables on the relationship between top management support and MAS.

Similarly, although the task uncertainty does not have a direct effect on the managers' performance (Hypothesis $4 b$ ), there is an indirect influence among these two latent variables resulting from the effect of task uncertainty on the information provided by the MAS, and then on the performance of the managers. This result could be explained by the presence of a total mediation of MAS.

Although the influence of information provided by MAS on organizational performance (Hypothesis 8b) has not been confirmed, there is an indirect influence exerted through the performance of the managers. As such, it seems that managers may be exercising full mediation in this type of relationship.

Finally, the uncertainty of the competitive environment has an indirect influence on the use of the information provided by the MAS through the decentralization of decisions. This result could be explained by the full mediation effect of decentralization of decisions on the direct relationship between competitive environmental uncertainty and MAS. 


\section{Discussion}

\subsection{Findings}

Based on the literature reviewed, to facilitate achieving our research's main objective, a new research instrument to measure the effectiveness of the information provided by MAS as a multidimensional, integrated and comprehensive concept was presented. This instrument consists of a second-order construct, which includes four first-order constructs representative of the dimensions of information most cited in the literature.

The four individual constructs representing the characteristics of information were considered adequate for the sample used, and representative of Portuguese SMEs. For this reason, MAS can be represented as a multidimensional construct, which manifests itself through the dimensions scope, timeliness, aggregation, and integration of information. This new approach was used to develop a research model that allowed the evaluation of the interaction of a multidimensional MAS with the main variables of the SME business environment. In this context, the results of the research model, which incorporates the multidimensional construct in its integrative form of the information provided by MAS, were analyzed. In the discussion of the results, although contextualized in the literature, the innovative nature of the proposed model should be considered and, therefore, also the inexistence of a comparative term.

Based on the results of this study, several organizational factors were found to be influencing the multidimensional utilization of MAS information. Regarding the top management support, the results confirmed the existence of a positive influence on the users' training, as well as the users' satisfaction with the information provided by the MAS. These findings are similar to the results obtained by Fong and Quaddus (2010) 
for the scope, timeliness, and aggregation. Increasing user training will, in turn, positively influence user satisfaction. The results also confirmed the positive influence on MAS both of user training and user satisfaction. The direct influence of top management support on MAS was found non-significant. In this context, it seems that the relationship between top management support and MAS may be full mediated by user training and user satisfaction.

Regarding the relationship between task uncertainty and the utilization of MAS information, the positive hypothesis was not confirmed. Instead, it seems that increased uncertainty in tasks could have a negative influence on the utilization of the information provided by MAS. As such, high levels of task uncertainty may be attributed to the lack of guidance to assist managers in the activities, which may reduce the use of the information provided by the MAS. A similar result was reported by Soobaroyen and Poorundersing (2008), although this was true only for the aggregation dimension of the information.

Concerning the influence of the decentralization of decisions on the utilization of MAS information, the positive relationship was confirmed. In organizations with greater decentralization of the decision-making process, the main decisions are usually taken by managers with greater access to information. As such, to increase decentralization, the use of information provided by the MAS should also increase. This finding contradicts the result obtained by Ern et al. (2016), but it was consistent with the results found by other authors (Chenhall and Morris, 1986; Soobaroyen and Poorundersing, 2008; Hammad, Jusoh and Ghozali, 2013). Chenhall and Morris (1986) found that, in a decentralized organizational environment, it is useful to have aggregated and 
integrated information. The results obtained by Hammad et al. (2013), showed a positive influence of the decentralization on the use of timely, aggregated and integrated information by the managers. Soobaroyen and Poorundersing (2008) concluded that there is a positive effect of decentralization on the availability of information in all its dimensions, individually (scope, timeliness, aggregation, and integration). Perhaps more research is needed to clarify this issue.

Regarding the accountant participation in the strategic decisions, no significant influence was found on the utilization of MAS information, which is contradictory to the result presented by Cadez and Guilding (2008). Again, more research is needed to clarify this issue.

Based on the results of this study, it was found that, in addition to organizational factors, also external competitive environment influences the multidimensional use of MAS information. It was expected that in situations of greater uncertainty of the competitive environment, managers would use more information available from the MAS. However, this hypothesis was not confirmed. A similar result was found by Harrison (2009) for the scope dimension, and by Chiou (2011) for scope, timeliness, and aggregation. Although the results of this study did not confirm the direct effect of the competitive environment uncertainty on the MAS, they revealed the existence of an indirect effect between these two variables, through the decentralization of decisions. Chenhall and Morris (1986) obtain a similar result only for the aggregation dimension. Therefore, it is suggested that more research is needed in his area.

Based on the results obtained it seems that the information provided by the MAS can have a direct and positive influence on the managers' performance, which is consistent 
with the findings of past studies (see Chong, 2004; Sharma, Jones and Ratnatunga, 2006; Soobaroyen and Poorundersing, 2008; Hammad, Jusoh and Ghozali, 2013; Ghasemi et al., 2016, 2019; Nguyen et al., 2017). However, while Soobaroyen and Poorundersing (2008) verified that all the individual dimensions of information (scope, timeliness, aggregation, and integration) influence the performance of managers, Ghasemi et al. (2019) and (Ghasemi et al., 2016) only verified that influence for the dimensions of scope, timeliness, and aggregation, and Hammad et al. (2013) only verified it for scope and timeliness. Sharma et al. (2006), Chong (2004), and Nguyen et al. (2017) obtained a similar result, only using the scope dimension. Therefore, in comparison with previous studies, it appears that more research is needed in this area.

The findings from this current research do not confirm the existence of a direct relationship between MAS and organizational performance, which is similar to those obtained by Harrison (2009) for the scope dimension, and different from the results obtained by Ismail et al. (2018) for all dimensions (scope, timeliness, aggregation, and integration), individually. However, our findings showed an indirect relationship between the MAS and the organizational performance, exercised through the performance of the managers. In this context, managers who use the information provided by MAS can make more reliable and faster decisions. In this way, they will improve their performance, which can influence the overall performance of their organization. These results tend to confirm the assumption that better performance by the managers is associated with better organizational performance (Chenhall, 2003). Based on the results of the current study, the managers' performance is influenced by three business environment factors, namely, the information of the MAS, the 
decentralization of decisions, and the competitive environment uncertainty. No evidence was found that task uncertainty has a direct influence on the managers' performance, which is similar to the results obtained by other authors (e.g., Chong, 2004; Soobaroyen and Poorundersing, 2008). However, an indirect effect of the task uncertainty on the managers' performance, through the MAS, was found.

Regarding organizational performance, the results confirmed the existence of a direct and positive relationship from the decentralization of decision-making power. However, the same does not apply to the participation of the accountant in the strategic decision-making process.

Regarding the decentralization of decisions, besides confirming a positive direct effect on organizational performance, there is also a positive indirect influence, exerted through the MAS. These results were consistent with the finding from Hoque (2011), who found that decentralization is directly and positively associated with the organization's performance.

The current study appears to confirm that in situations of greater uncertainty of the competitive environment, the instability felt by companies will negatively affect their performance. This result confirmed the findings of Harrison (2009). Besides this direct effect, there is also a negative indirect effect, exerted through the performance of the managers.

\subsection{Implications for theory}

Overall, the results of the structural model (Figure 2) appear to support the conceptual model presented in Figure 1. This conceptual model allowed for a systematic 
investigation of the direct and indirect relationships among the constructs of interest. It is to be pointed out that these constructs were designed based on the variables extracted from the literature and the feedback obtained from experts in this field. As such, the conceptual model is justified on two grounds. First, the literature review revealed the lack of such a comprehensive model. Second, the results of the structural model (Figure 2) appear to support their conceptualization (Figure 1). This model represents a modest attempt on the part of the researchers to gain insights into the relationships among the relevant constructs to the topic under investigation. Previous investigations of this issue focused on a single relationship between two variables. Therefore, the literature has discrete hypotheses rather than a model that allows for understanding the direct and indirect relationships of constructs. Our study attempted to shed some light on the multi and dynamic relationships as opposed to the approaches used in the literature.

The results of our study also contribute to the advancement of the knowledge of the contingency factors of the MAS and their influence on the performance of SMEs. Although confirming most of the single relationships reported in the literature, the hypotheses results need to be viewed as a starting point for future research, using this new multidimensional approach to measure MAS effectiveness. The effectiveness of MAS is contingent on the interaction among the different components of the system. Therefore, it is important to emphasize the design and implementation of this system. When designing such a system, the relationships and interfaces among this system and other organizational systems must be analyzed very carefully. For example, the 
relationship between the MAS and the performance measurement system needs to be defined in order to encourage synergy and integration.

\subsection{Implications for practice}

The insights gained due to this research should provide management professionals an advantage, as they evaluate the MAS in their organizations. In a competitive environment, whether organizations use a cost leadership or a differentiation strategy, they need a sound MAS in order to be able to track their competitive performance. This is essential to gaining and maintaining a competitive strategic advantage.

This study also brings practical contributions by identifying the factors which contribute to improving the utilization of the information provided by the MAS. In this context, managers can promote a self-assessment of their organizational performance using these factors. They can identify the areas of potential improvement and initiate innovative strategies that could enhance the influence on the characteristics of the information provided by the MAS.

\section{Conclusion}

In today's competitive environment, organizations that aspire to survive and grow will have to be continually changing and adapting to new and challenging realities. In this context, MAS should play key roles in the decision-making and benchmarking processes by providing detailed and timely information.

This study addresses three research questions and examined several hypotheses pertaining to the different characteristics, roles, and organizational impact of MAS on 
SMEs. For this purpose, a structural modeling approach was utilized to examine the relevant research hypotheses.

With regard to research question one, results suggest that the information provided by a multidimensional management accounting system (MAS), tend to influence the managers' performance. Regarding the influence of MAS on organizational performance, no significant direct relationship was found. However, it seems that a positive indirect relationship is obtained through the manager's performance. This means that the manager will use the MAS information to reduce the risk of competitive environment uncertainty, and thus increase organizational performance.

With regard to research question two, it seems that the decentralization of decisions will have a positive effect on the use of information provided by the MAS. No direct relationship was found between top management support and MAS utilization. However, support from top managers to the training of information users could promote increased use of MAS. There was a negative influence of task uncertainty on the use of MAS, which was not expected. Finally, it is noted that the competitive environment uncertainty will only indirectly influence MAS through increased decentralization of decisions. This could mean that companies respond to market uncertainty by decentralizing decisions, which in turn promotes greater use of MAS.

With regard to research question three, it appears that, as expected, the uncertainty of the environment has a negative effect on both managerial and organizational performance. Regarding the decentralization of decisions, the results also validated the literature, confirming a positive influence on both managerial and organizational performance. 
Based on the results derived from the multidimensional approach to the MAS, some relevant considerations are advocated. The innovative nature of the development and validation of a second-order factor that can measure the effectiveness of MAS should be emphasized. The role of benchmarking in this process can't be overlooked. In addition, the synergies resulting from the four dimensions of information are stressed. These synergies can be created through the balanced development of these four dimensions. This multidimensional approach, which was advocated by the instrument and research model utilized in this study, should enrich knowledge in the area of management accounting. This may offer researchers a valuable tool to measure the effectiveness of MAS and its influence on organizational performance. This, in turn, should facilitate the comparison between different studies of this field. The practical importance of sound benchmarking practices throughout this process is emphasized.

\section{Limitations}

While this study addressed relevant managerial decision-making practices, usage, and competitive issues pertaining to the different facets of organizational MAS, its findings are limited to the Portuguese organizational culture. Due to its importance, future research is called for in relation to the central role of MAS in different organizational cultural settings. In addition, future research with larger sample size is needed to solidify the bulk of evidence among the dynamic constructs proposed in this research rather than the mere single variable-to-variable relationship found in the literature. 


\section{Future research}

The proposed model is by no means offered as a definite one to uncover all the interactions linking the human elements (users and top management) to performance. Future researchers are invited to test, modify, and refine this exploratory model. This research should facilitate the formulation of new hypotheses and, consequently, shed more light on research dealing with the impact of MAS on modern organizations. This is especially true considering the increasing importance of information technology and related systems on the performance and competitiveness of modern organizations. Such systems are essential to the integration of information relevant to managerial decision-making, organizational performance, benchmarking, and overall competitiveness in the dynamic marketplace. This study offers a systematic organizational approach to understanding the role of the MAS. The model offered in this study is a modest attempt to understand the multiple facets of MAS. The refinement, modifications, and validation of this model are left for future research and potential organizational implementation in different organizational cultural business settings. 


\section{REFERENCES}

Aaltola, P. (2019) 'Strategic thinking and accounting: potentials and pitfalls from a managerial perspective', Journal of Management Control. Springer Berlin Heidelberg, 30, pp. 323-351. doi: 10.1007/s00187-019-00285-w.

Abdel-Kader, M. and Luther, R. (2008) 'The impact of firm characteristics on management accounting practices: A UK-based empirical analysis', The British Accounting Review, 40(1), pp. 2-27. doi: 10.1016/j.bar.2007.11.003.

Abdel-Maksoud, A. (2004) 'Manufacturing in the UK : contemporary characteristics and performance indicators', Journal of Manufacturing Technology Management, 15(2), pp. 155-171. doi: 10.1108/09576060410513742.

Abdel-Maksoud, A. et al. (2010) 'Employee morale, non-financial performance measures, deployment of innovative managerial practices and shop-floor involvement in Italian manufacturing firms', The British Accounting Review. Elsevier Ltd, 42(1), pp. 36-55. doi: 10.1016/j.bar.2010.01.002.

Agbejule, A. (2005) 'The relationship between management accounting systems and perceived environmental uncertainty on managerial performance: a research note', Accounting and Business Research, 35(4), pp. 295-305. doi: 10.1080/00014788.2005.9729996.

Agbejule, A. (2011) 'Organizational culture and performance: the role of management accounting system', Journal of Applied Accounting Research, 12(1), pp. 74-89. doi: 10.1108/09675421111130621.

Al-Sayed, M. and Dugdale, D. (2016) 'Activity-based innovations in the UK manufacturing sector: Extent, adoption process patterns and contingency factors', The British Accounting Review. Elsevier Ltd, 48(1), pp. 38-58. doi: 10.1016/j.bar.2015.03.004.

Alattar, J. M., Kouhy, R. and Innes, J. (2009) 'Management accounting information in micro enterprises in Gaza', Journal of Accounting \& Organizational Change, 5(1), pp. 81-107. doi: 10.1108/18325910910932223.

Ambe, C. M. and Sartorius, K. (2002) 'Competition and the performance of strategic business units - A study of the South African beverage industry', Meditari Accountancy Research, 10(1), pp. 1-23. doi: 10.1108/10222529200200001.

Anderson, J. C. and Gerbing, D. W. (1988) 'Structural equation modeling in practice: A review and recommended two-step approach', Psychological Bulletin, 103(3), pp. 411423. doi: 10.1037//0033-2909.103.3.411.

Aoki, H. and Miyajima, H. (2012) 'Benchmarking business unit governance in turbulent times: The case of Japanese firms', Benchmarking: An International Journal, 19(4), pp. 548-566. doi: 10.1108/14635771211258007.

Appelbaum, D. et al. (2017) 'Impact of business analytics and enterprise systems on managerial accounting', International Journal of Accounting Information Systems. Elsevier, 25(March), pp. 29-44. doi: 10.1016/j.accinf.2017.03.003.

Bartnik, R. and Park, Y. (2018) 'Technological change, information processing and 
supply chain integration: A conceptual model', Benchmarking: An International Journal, 25(5), pp. 1279-1301. doi: 10.1108/BIJ-03-2016-0039.

Bouwens, J. and Abernethy, M. A. (2000) 'The consequences of customization on management accounting system design', Accounting, Organizations and Society, 25(3), pp. 221-241. doi: 10.1016/S0361-3682(99)00043-4.

Cadez, S. and Guilding, C. (2008) 'An exploratory investigation of an integrated contingency model of strategic management accounting', Accounting, Organizations and Society. Elsevier Ltd, 33(7-8), pp. 836-863. doi: 10.1016/j.aos.2008.01.003.

Cadez, S. and Guilding, C. (2012) 'Strategy, strategic management accounting and performance: a configurational analysis', Industrial Management \& Data Systems, 112(3), pp. 484-501. doi: 10.1108/02635571211210086.

de Castro, V. F. and Frazzon, E. M. (2017) 'Benchmarking of best practices: an overview of the academic literature', Benchmarking, 24(3), pp. 750-774. doi: 10.1108/BIJ-032016-0031.

Chang, R. D., Chang, Y. W. and Paper, D. (2003) 'The effect of task uncertainty, decentralization and AIS characteristics on the performance of AIS: an empirical case in Taiwan', Information and Management, 40(7), pp. 691-703. doi: 10.1016/S03787206(02)00097-6.

Chenhall, R. H. (2003) 'Management control systems design within its organizational context: findings from contingency-based research and directions for the future', Accounting, Organizations and Society, 28(2-3), pp. 127-168. doi: 10.1016/S03613682(01)00027-7.

Chenhall, R. H. and Langfield-Smith, K. (1999) 'The implementation of innovative management accounting systems', Australian Accounting Review, 9(3), pp. 37-46.

Chenhall, R. H. and Morris, D. (1986) 'The Impact of Structure, Environment, and Interdependence on the Perceived Usefulness of Management Accounting Systems', The Accounting Review, 61(1), pp. 16-35.

Chiou, B. (2011) 'Which types of management accounting system information can be used to respond adequately to environmental uncertainty? The effects of user participation and tolerance of ambiguity', African Journal of Business Management, 5(34), pp. 13293-13301. doi: 10.5897/AJBM11.2207.

Chiu, V. et al. (2019) 'A bibliometric analysis of accounting information systems journals and their emerging technologies contributions', International Journal of Accounting Information Systems. Elsevier, 32(November 2018), pp. 24-43. doi: 10.1016/j.accinf.2018.11.003.

Choe, J. (2004) 'The relationships among management accounting information, organizational learning and production performance', The Journal of Strategic Information Systems, 13(1), pp. 61-85. doi: 10.1016/j.jsis.2004.01.001.

Chong, V. K. (2004) 'Job-Relevant Information and its Role with Task Uncertainty and Management Accounting Systems on Managerial Performance', Pacific Accounting Review, 16(2), pp. 1-22. doi: 10.1108/01140580410818496.

Cleary, P. (2009) 'Exploring the relationship between management accounting and 
structural capital in a knowledge-intensive sector', Journal of Intellectual Capital, 10(1), pp. 37-52. doi: 10.1108/14691930910922888.

Cohen, S. and Kaimenaki, E. (2011) 'Cost accounting systems structure and information quality properties: an empirical analysis', Journal of Applied Accounting Research, 12(1), pp. 5-25. doi: 10.1108/09675421111130586.

Conger, J. A. and Kanungo, R. N. (1988) 'The Empowerment Process: Integrating Theory and Practice.', Academy of Management Review, 13(3), pp. 471-482. doi: 10.5465/AMR.1988.4306983.

Curran, P. J., West, S. G. and Finch, J. F. (1996) 'The robustness of test statistics to nonnormality and specification error in confirmatory factor analysis.', Psychological Methods, 1(1), pp. 16-29.

Davila, A., Foster, G. and Oyon, D. (2009) 'Accounting and control, entrepreneurship and innovation: Venturing into new research opportunities', European Accounting Review, 18(2), pp. 281-311. doi: 10.1080/09638180902731455.

Ern, S. Y., Abdullah, A. and Yau, F. S. (2016) 'Contingency Factors Influencing MAS Design of Manufacturing Firms in Malaysia', Asian Journal of Accounting and Governance, 7, pp. 1-9. doi: 10.17576/AJAG-2016-07-01.

Erserim, A. (2012) 'The Impacts of Organizational Culture, Firm's Characteristics and External Environment of Firms on Management Accounting Practices: An Empirical Research on Industrial Firms in Turkey', Procedia - Social and Behavioral Sciences, 62(2011), pp. 372-376. doi: 10.1016/j.sbspro.2012.09.059.

Esparza-Aguilar, J. L., García-Pérez-De-Lema, D. and Duréndez, A. (2016) 'The effect of accounting information systems on the performance of Mexican micro, small and medium-sized family firms: An exploratory study for the hospitality sector', Tourism Economics, 22(5), pp. 1104-1120. doi: 10.5367/te.2015.0515.

Etemadi, H. et al. (2009) 'Culture, management accounting and managerial performance: Focus Iran', Advances in Accounting. Elsevier Ltd, 25(2), pp. 216-225. doi: 10.1016/j.adiac.2009.08.005.

Evans, J. R. (2007) 'Impacts of information management on business performance', Benchmarking: An International Journal, 14(4), pp. 517-533. doi: 10.1108/14635770710761906.

Fong, S. C. C. and Quaddus, M. (2010) 'Intranet use in Hong Kong public hospitals', International Journal of Accounting and Information Management, 18(2), pp. 156-181. doi: $10.1108 / 18347641011048138$.

Foster, G. and Swenson, D. W. (1997) 'Measuring the Success of Activity-Based Cost Management and Its Determinants', Journal of Management Accounting Research, 9, pp. 109-141. doi: 10.1080/01933928108411685.

Frezatti, F. et al. (2011) 'Does management accounting play role in planning process?', Journal of Business Research. Elsevier Inc., 64(3), pp. 242-249. doi: 10.1016/j.jbusres.2009.11.008.

Galbraith, J. (1973) Designing Complex Organizations. Reading, MA: Addison-Wesley. 
Galbraith, J. (1977) Organizational Design. Reading, MA: Addison-Wesley.

Garg, P. and Khurana, R. (2017) 'Applying structural equation model to study the critical risks in ERP implementation in Indian retail', Benchmarking: An International Journal, 24(1), pp. 143-162. doi: 10.1108/BIJ-12-2015-0122.

Ghasemi, R. et al. (2016) 'The mediating effect of management accounting system on the relationship between competition and managerial performance', International Journal of Accounting \& Information Management, 24(3), pp. 272-295. doi: 10.1108/IJAIM-05-2015-0030.

Ghasemi, R. et al. (2019) 'The effectiveness of management accounting systems: evidence from financial organizations in Iran', Journal of Accounting in Emerging Economies, 9(2), pp. 182-207. doi: 10.1108/JAEE-02-2017-0013.

Ghorbel, J. (2019) 'A Study of Contingency Factors of Accounting Information System Design in Tunisian SMIs', Journal of the Knowledge Economy. Journal of the Knowledge Economy, 10(1), pp. 74-103. doi: 10.1007/s13132-016-0439-8.

Gunarathne, A. D. N. and Lee, K.-H. (2019) 'Environmental and managerial information for cleaner production strategies: An environmental management development perspective', Journal of Cleaner Production. Elsevier Ltd, 237, p. 117849. doi: 10.1016/j.jclepro.2019.117849.

Guven-Uslu, P. (2005) 'Benchmarking in health services', Benchmarking: An International Journal, 12(4), pp. 293-309. doi: 10.1108/14635770510608999.

Hair, J. F. et al. (2014) Multivariate Data Analysis. Seventh ed. Pearson Education Limited.

Halabi, A. K., Barrett, R. and Dyt, R. (2010) 'Understanding financial information used to assess small firm performance: An Australian qualitative study', Qualitative Research in Accounting \& Management, 7(2), pp. 163-179. doi: 10.1108/11766091011050840.

Hall, M. (2008) 'The effect of comprehensive performance measurement systems on role clarity, psychological empowerment and managerial performance', Accounting, Organizations and Society, 33(2-3), pp. 141-163. doi: 10.1016/j.aos.2007.02.004.

Hammad, S. A., Jusoh, R. and Ghozali, I. (2013) 'Decentralization, perceived environmental uncertainty, managerial performance and management accounting system information in Egyptian hospitals', International Journal of Accounting and Information Management, 21(4), pp. 314-330. doi: 10.1108/IJAIM-02-2012-0005.

Hariyati, H. and Tjahjadi, B. (2018) 'Contingent Factors Affecting the Financial Performance of Manufacturing Companies: The Case of East Java, Indonesia', Asian Journal of Business and Accounting, 11(1), pp. 121-150. doi: 10.22452/ajba.vol11no1.5.

Hariyati, H., Tjahjadi, B. and Soewarno, N. (2019) 'The mediating effect of intellectual capital, management accounting information systems, internal process performance, and customer performance', International Journal of Productivity and Performance Management, pp. 1250-1271. doi: 10.1108/IJPPM-02-2018-0049.

Harrison, J. L. (2009) 'Untangling the value of information scope: An investigation in retail pharmacies', Journal of Management and Organization, 15(4), pp. 470-485. doi: 
10.5172/jmo.15.4.470.

Heidmann, M., Schäffer, U. and Strahringer, S. (2008) 'Exploring the Role of Management Accounting Systems in Strategic Sensemaking', Information Systems Management, 25(3), pp. 244-257. doi: 10.1080/10580530802151194.

Hong, P. et al. (2012) 'Evolving benchmarking practices: a review for research perspectives', Benchmarking: An International Journal, 19(4/5), pp. 444-462.

Hoque, Z. (2011) 'The relations among competition, delegation, management accounting systems change and performance: A path model', Advances in Accounting. Elsevier Ltd, 27(2), pp. 266-277. doi: 10.1016/j.adiac.2011.05.006.

Hoyle, R. H. (1995) 'The structural equation modeling approach: basic concepts and fundamental issues', in Sage Publications, I. (ed.) Structural Equation Modeling: Concepts, Issues, and Applications. R.H. Hoyle. Thousand Oaks, CA, pp. 1-15.

Huang, H. C., Lai, M. C. and Lin, T. H. (2011) 'Aligning intangible assets to innovation in biopharmaceutical industry', Expert Systems with Applications. Elsevier Ltd, 38(4), pp. 3827-3834. doi: 10.1016/j.eswa.2010.09.043.

Ismail, K., Isa, C. R. and Mia, L. (2018) 'Evidence on the usefulness of management accounting systems in integrated manufacturing environment', Pacific Accounting Review, 30(1), pp. 2-19. doi: 10.1108/PAR-04-2015-0010.

Jansen, J. J. P., Van den Bosch, F. A. J. and Volberda, H. W. (2006) 'Exploratory Innovation, Exploitative Innovation, and Performance: Effects of Organizational Antecedents and Environmental Moderators', Management Science, 52(11), pp. 16611674.

Kocsis, D. (2019) 'A conceptual foundation of design and implementation research in accounting information systems', International Journal of Accounting Information Systems. Elsevier Inc., 34, p. 100420. doi: 10.1016/j.accinf.2019.06.003.

Krumwiede, K. R. (1998) 'The implementation stages of activity-based costing and the impact of contextual and organizational factors', Journal of Management Accounting Research, 10, pp. 239-277.

Krumwiede, K. R., Suessmair, A. and MacDonald, J. (2008) 'An exploratory study of the factors affecting the implementation success of German cost accounting methods', in AAA 2008 MAS Meeting Paper, pp. 1-54.

Linn, G. et al. (2001) 'Do broad scope managerial accounting systems moderate the effects of budget emphasis, budget participation and perceived environmental uncertainty on the propensity to create budgetary slack?', Journal of Computer Information Systems, 42(1), pp. 90-96.

Macinati, M. S. and Anessi-Pessina, E. (2014) 'Management accounting use and financial performance in public health-care organisations: Evidence from the Italian National Health Service', Health Policy, 117(1), pp. 98-111. doi: 10.1016/j.healthpol.2014.03.011.

Marchand, M. and Raymond, L. (2018) 'Characterising performance measurement systems as used in SMEs: a field study', Benchmarking: An International Journal, 25(8), pp. 3253-3275. doi: 10.1108/BIJ-12-2017-0346. 
Mendoza, C. and Bescos, P.-L. (2001) 'An explanatory model of managers' information needs: implications for management accounting', European Accounting Review, 10(2), pp. 257-289. doi: 10.1080/713764598.

Mollanazari, M. and Abdolkarimi, E. (2012) 'The Effects of Task, Organization and Accounting Information Systems Characteristics on the Accounting Information Systems Performance in Tehran Stock Exchange', International Journal of Innovation, Management and Technology, 3(4), pp. 443-448.

Moores, K. and Yuen, S. (2001) 'Management accounting systems and organizational configuration: A life-cycle perspective', Accounting, Organizations and Society, 26(45), pp. 351-389. doi: 10.1016/S0361-3682(00)00040-4.

Naranjo-Gil, D. (2009) 'Management information systems and strategic performances: The role of top team composition', International Journal of Information Management, 29(2), pp. 104-110. doi: 10.1016/j.ijinfomgt.2008.05.009.

Naranjo-Gil, D. and Hartmann, F. (2007) 'Management accounting systems, top management team heterogeneity and strategic change', Accounting, Organizations and Society, 32(7-8), pp. 735-756.

Nguyen, T. T. et al. (2017) 'Effect of transformational-leadership style and management control system on managerial performance', Journal of Business Research. Elsevier Inc., 70, pp. 202-213. doi: 10.1016/j.jbusres.2016.08.018.

Oesterreich, T. D. et al. (2019) 'The controlling profession in the digital age: Understanding the impact of digitisation on the controller's job roles, skills and competences', International Journal of Accounting Information Systems. Elsevier Inc., 35, p. 100432. doi: 10.1016/j.accinf.2019.100432.

Otley, D. (2016) 'The contingency theory of management accounting and control: 19802014', Management Accounting Research. Elsevier Ltd, 31, pp. 45-62. doi: 10.1016/j.mar.2016.02.001.

Pärl, Ü. (2014) 'The role of dialogue between executives and ground-level employees mediated by MACS', Baltic Journal of Management, 9(2), pp. 189-212.

Pelz, M. (2019) 'Can Management Accounting Be Helpful for Young and Small Companies? Systematic Review of a Paradox', International Journal of Management Reviews, 21(2), pp. 256-274. doi: 10.1111/ijmr.12197.

Perego, P. and Hartmann, F. (2009) 'Aligning performance measurement systems with strategy: The case of environmental strategy', Abacus, 45(4), pp. 397-428. doi: 10.1111/j.1467-6281.2009.00297.x.

Peters, M. D., Wieder, B. and Sutton, S. G. (2018) 'Organizational improvisation and the reduced usefulness of performance measurement $\mathrm{BI}$ functionalities', International Journal of Accounting Information Systems. Elsevier, 29(March), pp. 1-15. doi: 10.1016/j.accinf.2018.03.005.

Pfister, J. A. and Lukka, K. (2019) 'Interrelation of Controls for Autonomous Motivation: A Field Study of Productivity Gains Through Pressure-Induced Process Innovation', The Accounting Review, 94(3), pp. 345-371. doi: 10.2308/accr-52266.

Pizzini, M. J. (2006) 'The relation between cost-system design, managers' evaluations 
of the relevance and usefulness of cost data, and financial performance: An empirical study of US hospitals', Accounting, Organizations and Society, 31(2), pp. 179-210. doi: 10.1016/j.aos.2004.11.001.

Podsakoff, P. M. et al. (2003) 'Common method biases in behavioral research: a critical review of the literature and recommended remedies', Journal of Applied Psychology, 88(5), pp. 879-903.

Pondeville, S., Swaen, V. and De Rongé, Y. (2013) 'Environmental management control systems: The role of contextual and strategic factors', Management Accounting Research. Elsevier Ltd, 24(4), pp. 317-332. doi: 10.1016/j.mar.2013.06.007.

Rai, A., Lang, S. S. and Welker, R. B. (2002) 'Assessing the validity of IS success models: An empirical test and theoretical analysis', Information Systems Research, 13(1), pp. 50-69. doi: 10.1287/isre.13.1.50.96.

Ramli, I. and Iskandar, D. (2014) 'Control authority, business strategy, and the characteristics of management accounting information systems', Procedia-Social and Behavioral Sciences. Elsevier B.V., 164(August), pp. 384-390. doi: 10.1016/j.sbspro.2014.11.092.

Ravichandran, T. and Lertwongsatien, C. (2005) 'Effect of information systems resources and capabilities on firm performance: a resource-based perspective', Journal of Management Information Systems, 21(4), pp. 237-276.

Raymond, L. et al. (2019) 'Determinants and outcomes of IT governance in manufacturing SMEs: A strategic IT management perspective', International Journal of Accounting Information Systems. Elsevier Inc., 35, p. 100422 . doi: 10.1016/j.accinf.2019.07.001.

Rickards, R. C. (2003) 'Setting benchmarks and evaluating balanced scorecards with data envelopment analysis', Benchmarking: An International Journal, 10(3), pp. 226245. doi: 10.1108/14635770310477762.

Sharma, R., Jones, S. and Ratnatunga, J. (2006) 'The relationships among broad scope MAS, managerial control, performance, and job relevant information: A concomitant analysis', Review of Accounting and Finance, 5(3), pp. 228-250. doi: $10.1108 / 14757700610686435$.

Shields, M. D. (1995) 'An empirical analysis of firms' implementation experiences with activity-based costing', Journal of Management Accounting Research, 7, pp. 148-166. Available at: http://proquest.umi.com/pqdweb?did=7573843\&Fmt=7\&clientld=23852\&RQT=309\& VName=PQD.

Soobaroyen, T. and Poorundersing, B. (2008) 'The effectiveness of management accounting systems: Evidence from functional managers in a developing country', Managerial Auditing Journal, 23(2), pp. 187-219.

Suwardy, T. et al. (2003) 'IT projects: Evaluation, outcomes and impediments', Benchmarking: An International Journal, 10(4), pp. 325-342. doi: 10.1108/14635770310484962.

Tabachnick, B. G. and Fidell, L. S. (2007) Using Multivariate Statistics. 5th edn. New 
York: Allyn and Bacon.

Tontiset, N. and Ussahawanitchakit, P. (2010) 'Building Successful Cost Accounting Implementation of Electronics Manufacturing Businesses in Thailand: How Do its Antecedents and Consequences Play a Significant Role?', Journal of Academy of Business and Economics, 10(3), pp. 1-24.

Tsamenyi, M., Sahadev, S. and Qiao, Z. S. (2011) 'The relationship between business strategy, management control systems and performance: Evidence from China', Advances in Accounting. Elsevier Ltd, 27(1), pp. 193-203. doi: 10.1016/j.adiac.2011.05.001.

Tuanmat, T. Z. and Smith, M. (2011) 'Changes in management accounting practices in Malaysia', Asian Review of Accounting, 19(3), pp. 221-242. doi: 10.1108/13217341111185146.

Velez, M. L. et al. (2015) 'How control system information characteristics affect exporter-intermediary relationship quality', International Business Review. Elsevier Ltd, 24(5), pp. 812-824. doi: 10.1016/j.ibusrev.2015.02.008.

Walker, H. et al. (2015) 'Theoretical perspectives in operations management: an analysis of the literature', International Journal of Operations \& Production Management, 35(8), pp. 1182-1206. doi: 10.1108/IJOPM-02-2014-0089.

Waterhouse, J. H. and Tiessen, P. (1978) 'A contingency framework for management accounting systems research', Accounting, Organizations and Society, 21(4), pp. 65-76.

Williams, J. J. and Seaman, A. E. (2002) 'Management accounting systems change and departmental performance: The influence of managerial information and task uncertainty', 13(4), pp. 419-445.

Wooldridge, B. and Floyd, S. W. (1990) 'The Strategy Process, Middle Management Involvement, and Organizational Performance', Strategic Management Journal, 11(3), pp. 231-241. doi: 10.1016/0024-6301(90)90349-9.

Yasin, M. M. (2002) 'The theory and practice of benchmarking: Then and now', Benchmarking: An International Journal, 9(3), pp. 217-243. doi: 10.1108/14635770210428992.

Zyznarska-Dworczak, B. (2018) 'The development perspectives of sustainable management accounting in central and Eastern European countries', Sustainability (Switzerland), 10(5), pp. 1-21. doi: 10.3390/su10051445. 


\section{APPENDIX A - Descriptive statistics of the survey answers}

\begin{tabular}{|c|c|c|c|c|c|c|}
\hline Code & Construct Items & Mean & S.E. & S.D. & Skew. & Kurt \\
\hline SCO01 & Information which relates to possible future events (e.g. new projects) & 4.38 & 0.091 & 1.45 & 0.193 & -0.680 \\
\hline SCOO2 & $\begin{array}{l}\text { Quantification of the likelihood of futures events occurring (e.g., } \\
\text { probability estimates) }\end{array}$ & 4.39 & 0.091 & 1.46 & 0.104 & -0.814 \\
\hline $\mathrm{SCOO3}$ & $\begin{array}{l}\text { Non-economic information (e.g., customer preferences, employee } \\
\text { attitudes, labor relations, attitudes of government and consumer } \\
\text { bodies, competitive threats, etc.) }\end{array}$ & 3.72 & 0.091 & 1.46 & 0.347 & -0.394 \\
\hline TIM01 & Requested information to arrive immediately upon request & 4.67 & 0.085 & 1.36 & 0.069 & -0.487 \\
\hline TIM02 & $\begin{array}{l}\text { Reports are provided frequently on a systematic, regular basis (e.g., } \\
\text { daily reports, weekly reports) }\end{array}$ & 5.11 & 0.090 & 1.43 & -0.162 & -1.037 \\
\hline TIM03 & $\begin{array}{l}\text { There is no delay between an event occurring and relevant } \\
\text { information being reported to you }\end{array}$ & 4.54 & 0.086 & 1.37 & 0.055 & -0.806 \\
\hline AGG01 & $\begin{array}{l}\text { Information provided on the different sections or functional areas in } \\
\text { your organization (e.g. marketing and production, or sales, cost, or } \\
\text { profit centers) }\end{array}$ & 4.82 & 0.089 & 1.42 & -0.152 & -0.636 \\
\hline AGG02 & $\begin{array}{l}\text { Information on the effect of events on particular time periods (e.g., } \\
\text { monthly / quarterly / annual summaries, trends, comparisons, etc.) }\end{array}$ & 4.73 & 0.082 & 1.31 & -0.015 & -0.662 \\
\hline AGG03 & $\begin{array}{l}\text { Information which has been processed to show the influence of } \\
\text { events on different functions (e.g., marketing or production associated } \\
\text { with particular activities or tasks) }\end{array}$ & 4.11 & 0.086 & 1.37 & 0.142 & -0.437 \\
\hline AGG04 & $\begin{array}{l}\text { Information on the effect of different sections' activities on summary } \\
\text { reports (e.g., profit, cost, revenue reports) for your particular sections } \\
\text { and for the overall organization }\end{array}$ & 4.48 & 0.086 & 1.37 & 0.101 & -0.671 \\
\hline AGG05 & $\begin{array}{l}\text { Information in formats suitable for input into decision models (e.g., } \\
\text { discounted cash flow analysis, incremental or marginal analysis, } \\
\text { inventory analysis, credit policy analysis, etc.) }\end{array}$ & 4.49 & 0.098 & 1.57 & 0.023 & -0.886 \\
\hline INT01 & $\begin{array}{l}\text { Information on the impact that your decision will have throughout } \\
\text { your department, and the influence of other individuals' decisions on } \\
\text { your area of responsibility }\end{array}$ & 4.50 & 0.096 & 1.53 & -0.024 & -0.814 \\
\hline INT02 & Precise targets for the activities of all sections within your department & 4.96 & 0.093 & 1.48 & -0.435 & -0.400 \\
\hline INT03 & $\begin{array}{l}\text { Information that relates to the impact that your decisions have on the } \\
\text { performance of your department }\end{array}$ & 5.00 & 0.088 & 1.41 & -0.341 & -0.603 \\
\hline MAP01 & $\begin{array}{l}\text { Planning: determining goals, policies, and courses of action (e.g., work } \\
\text { scheduling, budgeting, and programming) }\end{array}$ & 5.20 & 0.063 & 1.00 & -0.152 & 0.087 \\
\hline MAP02 & $\begin{array}{l}\text { Investigating: collecting and preparing of information usually in the } \\
\text { form of records, reports, and accounts (e.g., measuring output, record } \\
\text { keeping, and job analysis) }\end{array}$ & 5.42 & 0.063 & 1.00 & -0.164 & -0.255 \\
\hline MAP03 & $\begin{array}{l}\text { Coordinating: exchanging information with people in the organization } \\
\text { other than my subordinates in order to relate and adjust procedures, } \\
\text { policies, and programs }\end{array}$ & 5.30 & 0.065 & 1.04 & -0.326 & -0.034 \\
\hline MAP04 & $\begin{array}{l}\text { Evaluating: assessment and appraisal of proposals or of } \\
\text { reported/observed performance (e.g., employee appraisals, judging } \\
\text { financial performance and product inspection) }\end{array}$ & 4.98 & 0.066 & 1.06 & -0.258 & 0.091 \\
\hline MAP05 & Supervising: directing, leading, and developing your subordinates & 5.24 & 0.063 & 1.00 & -0.233 & 0.265 \\
\hline MAP06 & $\begin{array}{l}\text { Staffing: maintaining the work force of your responsibility area (e.g., } \\
\text { selecting and promoting your subordinates) }\end{array}$ & 5.09 & 0.065 & 1.03 & -0.147 & 0.271 \\
\hline MAP07 & $\begin{array}{l}\text { Negotiating: purchasing, selling, or contracting for products or services } \\
\text { (e.g., contracting suppliers, collective bargaining)* }\end{array}$ & 4.97 & 0.068 & 1.08 & -0.378 & 0.476 \\
\hline MAP08 & $\begin{array}{l}\text { Representing: Promote the general interests of the company } \\
\text { externally (e.g., participate in conventions, consultations with other } \\
\text { companies, groups or individuals, public speeches, interaction with } \\
\text { the community) }\end{array}$ & 4.81 & 0.079 & 1.26 & -0.412 & 0.193 \\
\hline MAP09 & $\begin{array}{l}\text { On overall, how would you rate your performance? ('not applicable' is } \\
\text { not an option) }\end{array}$ & 5.35 & 0.049 & 0.78 & -0.105 & -0.014 \\
\hline
\end{tabular}

Notes: SE - Standard error; SD - Standard deviation; Skew - Skewness; Kurt - Kurtosis; * - Excluded based on the measurement model estimation process. 
APPENDIX A (Cont.)

\begin{tabular}{|c|c|c|c|c|c|c|}
\hline Code & Variables & Mean & S.E. & S.D. & Skew. & Kurt \\
\hline ORP01 & Return on investment & 4.94 & 0.062 & 1.00 & 0.007 & 0.265 \\
\hline ORP02 & Margin on sales & 4.84 & 0.063 & 1.01 & 0.107 & -0.457 \\
\hline ORPO3 & Capacity utilization & 4.98 & 0.059 & 0.95 & 0.067 & -0.169 \\
\hline ORP04 & Customer satisfaction & 5.39 & 0.054 & 0.86 & -0.057 & -0.517 \\
\hline ORP05 & Product quality* & 5.67 & 0.053 & 0.84 & -0.150 & -0.559 \\
\hline ORP06 & Development of new products* & 4.85 & 0.071 & 1.13 & -0.187 & -0.097 \\
\hline ORP07 & Market share & 4.96 & 0.065 & 1.04 & -0.159 & -0.045 \\
\hline USA01 & Reliability of output information & 5.50 & 0.062 & 1.00 & -1.370 & 2.000 \\
\hline USA02 & Relevancy of output information to intended function & 5.53 & 0.061 & 0.97 & -1.253 & 1.899 \\
\hline USA03 & Accuracy of output information & 5.14 & 0.070 & 1.12 & -0.667 & -0.182 \\
\hline USA04 & Precision of output information* & 5.24 & 0.066 & 1.06 & -0.772 & 0.325 \\
\hline USA05 & Completeness of the output information & 5.20 & 0.062 & 0.99 & -0.975 & 0.870 \\
\hline UTR01 & $\begin{array}{l}\text { Users received adequate training in designing of our management } \\
\text { accounting system }\end{array}$ & 4.91 & 0.086 & 1.37 & -0.799 & -0.224 \\
\hline UTR02 & $\begin{array}{l}\text { Adequate training was (is) provided for implementing the } \\
\text { management accounting system }\end{array}$ & 4.92 & 0.084 & 1.34 & -0.913 & 0.210 \\
\hline UTR03 & $\begin{array}{l}\text { Users have had adequate training in how to use the information } \\
\text { provided management accounting system }\end{array}$ & 5.00 & 0.083 & 1.33 & -0.970 & 0,357 \\
\hline TMS01 & $\begin{array}{l}\text { The management accounting system receives strong active support } \\
\text { from top management }\end{array}$ & 5.64 & 0.072 & 1.16 & -1.136 & 1.211 \\
\hline TMSO2 & $\begin{array}{l}\text { Upper management has provided adequate resources to } \\
\text { implement/maintain the management accounting system }\end{array}$ & 5.38 & 0.071 & 1.14 & -1.012 & 1.093 \\
\hline TMSO3 & $\begin{array}{l}\text { The management accounting system is closely tied to the competitive } \\
\text { strategies of our business* }\end{array}$ & 5.60 & 0.072 & 1.16 & -1.164 & 1.538 \\
\hline TUN01 & $\begin{array}{l}\text { There is a clearly defined body of knowledge which can guide me in } \\
\text { doing my work }\end{array}$ & 2.22 & 0.059 & 0.94 & 1.396 & 3.077 \\
\hline TUNO2 & I think that my work is routine* & 4.49 & 0.096 & 1.53 & -0.145 & -1.093 \\
\hline TUN03 & $\begin{array}{l}\text { There a clearly known way to do the major types of work I normally } \\
\text { encounter }\end{array}$ & 2.74 & 0.073 & 1.17 & 1.149 & 1.320 \\
\hline TUN04 & $\begin{array}{l}\text { There is an understandable sequence of steps that can be followed in } \\
\text { doing my work }\end{array}$ & 2.69 & 0.071 & 1.14 & 1.165 & 1.853 \\
\hline DEC01 & Development of new products or services & 4.11 & 0.104 & 1.66 & -0.244 & -0.790 \\
\hline DEC02 & The hiring and firing of managerial personnel & 3.63 & 0.106 & 1.69 & -0.055 & -0.988 \\
\hline DEC03 & Major investments decisions & 3.63 & 0.114 & 1.83 & 0.069 & -1.004 \\
\hline DEC04 & Budget allocation & 4.25 & 0.100 & 1.60 & -0.276 & -0.534 \\
\hline DEC05 & Pricing decisions & 4.13 & 0.104 & 1.67 & -0.249 & -0.736 \\
\hline APD01 & Identifying problems and proposing objectives* & 4.29 & 0.095 & 1.52 & -0.379 & -0.474 \\
\hline APD02 & Generating strategic options & 4.20 & 0.099 & 1.58 & -0.412 & -0.501 \\
\hline APD03 & Evaluating strategic options & 4.21 & 0.103 & 1.64 & -0.440 & -0.576 \\
\hline APD04 & Developing details about strategic options & 4.30 & 0.099 & 1.59 & -0.428 & -0.491 \\
\hline APD05 & Taking the necessary actions to put changes into place* & 4.51 & 0.093 & 1.48 & -0.463 & -0.312 \\
\hline CEU01 & The rate at which products and services become outdated & 4.00 & 0.105 & 1.67 & -0.234 & -0.825 \\
\hline CEU02 & The rate at which marketing practices are changing & 4.36 & 0.089 & 1.42 & -0.408 & -0.210 \\
\hline CEU03 & The tastes and preferences of customers in your industry & 4.29 & 0.103 & 1.64 & -0.289 & -0.687 \\
\hline CEU04 & Actions of competitors & 4.62 & 0.093 & 1.48 & -0.461 & -0.339 \\
\hline CEU05 & The rate of change of product/service technology & 4.72 & 0.097 & 1.55 & -0.473 & -0.287 \\
\hline
\end{tabular}

Notes: SE - Standard error; SD - Standard deviation; Skew - Skewness; Kurt - Kurtosis; * - Excluded based on the measurement model estimation process 
Table 1 - Dimensions of information characteristics provided by MAS

\begin{tabular}{|c|c|c|c|c|}
\hline Authors & Scope & Timeliness & Aggregation & Integration \\
\hline Chenhall and Morris (1986) & $\mathrm{X}$ & $\mathrm{X}$ & $\mathrm{X}$ & $\mathrm{X}$ \\
\hline Bouwens and Abernethy (2000) & $\mathrm{X}$ & $\mathrm{X}$ & $\mathrm{X}$ & $\mathrm{X}$ \\
\hline Linn et al. (2001) & $\mathrm{X}$ & - & - & - \\
\hline Moores and Yuen (2001) & $\mathrm{X}$ & $\mathrm{x}$ & $\mathrm{X}$ & $x$ \\
\hline Chang et al., (2003) & $x$ & $x$ & $\mathrm{X}$ & - \\
\hline Chong (2004) & $\mathrm{X}$ & - & - & - \\
\hline Agbejule (2005) & $\mathrm{X}$ & $\mathrm{X}$ & $\mathrm{X}$ & $x$ \\
\hline Sharma et al. (2006) & $\mathrm{X}$ & - & - & - \\
\hline Naranjo-Gil and Hartmann (2007) & $\mathrm{X}$ & - & - & - \\
\hline Soobaroyen and Poorundersing (2008) & $\mathrm{X}$ & $\mathrm{X}$ & $\mathrm{x}$ & $x$ \\
\hline Heidmann et al. (2008) & $x$ & $\mathrm{x}$ & - & - \\
\hline Etemadi et al. (2009) & $\mathrm{X}$ & $\mathrm{X}$ & - & - \\
\hline Harrison (2009) & $\mathrm{X}$ & - & - & - \\
\hline Naranjo-Gil (2009) & $\mathrm{X}$ & $x$ & $\mathrm{X}$ & $\mathrm{X}$ \\
\hline Perego and Hartmann (2009) & $x$ & $\mathrm{x}$ & - & - \\
\hline Fong and Quaddus (2010) & $\mathrm{X}$ & $\mathrm{X}$ & $x$ & - \\
\hline Chiou (2011) & $x$ & $\mathrm{X}$ & $\mathrm{X}$ & - \\
\hline Frezatti et al. (2011) & $\mathrm{X}$ & $\mathrm{X}$ & $\mathrm{X}$ & $\mathrm{X}$ \\
\hline Mollanazari and Abdolkarimi (2012) & $\mathrm{X}$ & $x$ & $x$ & - \\
\hline Hammad et al. (2013) & $\mathrm{X}$ & $\mathrm{X}$ & $\mathrm{X}$ & $x$ \\
\hline Pondeville et al. (2013) & $\mathrm{x}$ & - & - & - \\
\hline Ramli and Iskandar (2014) & $\mathrm{X}$ & $\mathrm{X}$ & $x$ & $x$ \\
\hline Velez et al. (2015) & $\mathrm{X}$ & $\mathrm{x}$ & $\mathrm{x}$ & $x$ \\
\hline Ern et al. (2016) & $\mathrm{x}$ & $\mathrm{X}$ & $x$ & $x$ \\
\hline Ghasemi et al. (2016) & $x$ & $x$ & $x$ & $x$ \\
\hline Esparza-Aguilar et al. (2016) & $x$ & $x$ & $x$ & $x$ \\
\hline Nguyen et al. (2017) & $x$ & - & - & - \\
\hline Ismail et al. (2018) & $\mathrm{X}$ & $x$ & $\mathrm{X}$ & $x$ \\
\hline Hariyati and Tjahjadi (2018) & $\mathrm{X}$ & $x$ & $x$ & $x$ \\
\hline Ghasemi et al. (2019) & $\mathrm{X}$ & $\mathrm{X}$ & $\mathrm{X}$ & $\mathrm{X}$ \\
\hline Hariyati et al. (2019) & $\mathrm{X}$ & $\mathrm{X}$ & $\mathrm{X}$ & $x$ \\
\hline Gunarathne and Lee (2019) & $\mathrm{X}$ & $\mathrm{X}$ & $\mathrm{X}$ & $x$ \\
\hline Ghorbel (2019) & $\mathrm{X}$ & $x$ & $x$ & - \\
\hline
\end{tabular}


Table 2a-Sample Profile

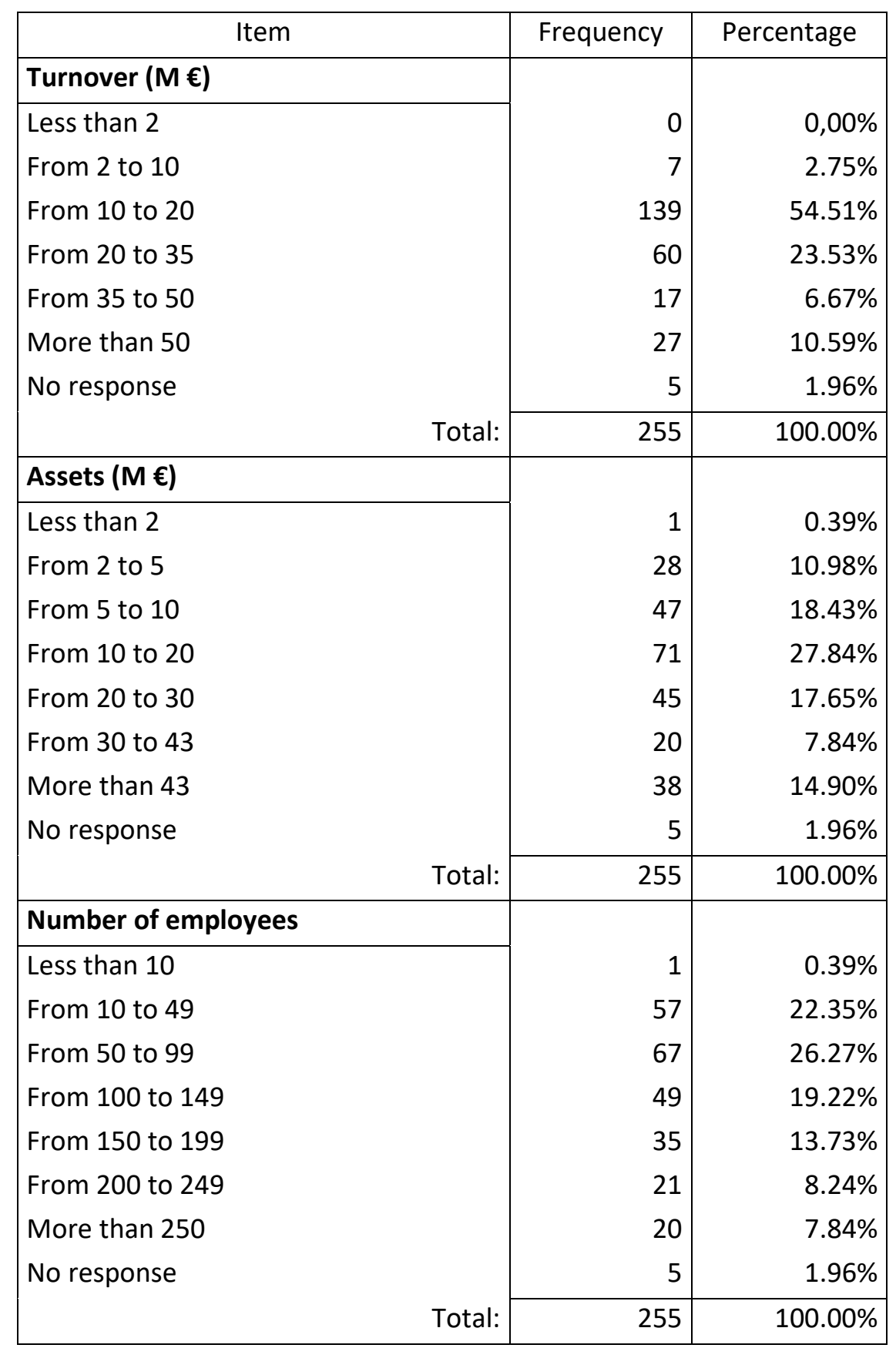


Table 2b-Sample Profile

\begin{tabular}{|c|c|c|}
\hline Industry & Frequency & Percentage \\
\hline $\begin{array}{l}\text { Wholesale trade and commission trade, except motor vehicles and } \\
\text { motorcycles }\end{array}$ & 45 & $17.65 \%$ \\
\hline Manufacture of food products and beverages & 30 & $11.76 \%$ \\
\hline $\begin{array}{l}\text { Sale, maintenance, and repair of motor vehicles and motorcycles; retail } \\
\text { sale of automotive fuel }\end{array}$ & 20 & $7.84 \%$ \\
\hline Construction & 19 & $7.45 \%$ \\
\hline Manufacture of electrical machinery and apparatus n.e.c. & 14 & $5.49 \%$ \\
\hline $\begin{array}{l}\text { Manufacture of fabricated metal products, except machinery and } \\
\text { equipment }\end{array}$ & 11 & $4.31 \%$ \\
\hline Manufacture of other non-metallic mineral products & 9 & $3.53 \%$ \\
\hline Manufacture of machinery and equipment n.e.c. & 8 & $3.14 \%$ \\
\hline $\begin{array}{l}\text { Retail trade, except motor vehicles and motorcycles; repair of personal } \\
\text { and household goods }\end{array}$ & 8 & $3.14 \%$ \\
\hline Supporting and auxiliary transport activities; activities of travel agencies & 7 & $2.75 \%$ \\
\hline Manufacture of chemicals and chemical products & 6 & $2.35 \%$ \\
\hline Manufacture of rubber and plastics products & 6 & $2.35 \%$ \\
\hline Computer and related activities & 6 & $2.35 \%$ \\
\hline Manufacture of textiles & 5 & $1.96 \%$ \\
\hline Land transport; transport via pipelines & 5 & $1.96 \%$ \\
\hline Other business activities & 5 & $1.96 \%$ \\
\hline $\begin{array}{l}\text { Tanning and dressing of leather; manufacture of luggage, handbags, } \\
\text { saddlery, harness, and footwear }\end{array}$ & 4 & $1.57 \%$ \\
\hline Manufacture of motor vehicles, trailers, and semi-trailers & 4 & $1.57 \%$ \\
\hline Financial intermediation, except insurance and pension funding & 4 & $1.57 \%$ \\
\hline Miscellaneous (with less than three occurrences) & 37 & $14.51 \%$ \\
\hline \multirow[t]{2}{*}{ No response } & 2 & $0.78 \%$ \\
\hline & 255 & $100.00 \%$ \\
\hline
\end{tabular}


Table 3 - Operationalization of the constructs

\begin{tabular}{|c|c|c|}
\hline Constructs & Scale & Sources \\
\hline $\begin{array}{l}\text { Management } \\
\text { accounting systems* }\end{array}$ & $\begin{array}{l}\text { The extent of use of MAS information on a 7- } \\
\text { point scale that could range from "never" (1) to } \\
\text { "always" (7). }\end{array}$ & $\begin{array}{l}\text { Chenhall and Morris (1986), } \\
\text { Bouwens and Abernethy } \\
\text { (2000); Naranjo-Gil (2009) }\end{array}$ \\
\hline $\begin{array}{l}\text { Managerial } \\
\text { performance** }\end{array}$ & $\begin{array}{l}\text { Self-evaluation of manager performance for } \\
\text { each of their activities on a 7-point scale that } \\
\text { could range from "unacceptable" (1) to } \\
\text { "excellent" (7) }\end{array}$ & $\begin{array}{l}\text { Mahoney et al. (1963), } \\
\text { Agbejule (2005), Hall (2008, } \\
\text { Sharma et al. (2006). }\end{array}$ \\
\hline $\begin{array}{l}\text { Organizational } \\
\text { performance }\end{array}$ & $\begin{array}{l}\text { Evaluation of organizational performance for } \\
\text { each of the performance measures included in } \\
\text { the construct, on a 7-point scale that could } \\
\text { range from "unacceptable" (1) to "excellent" } \\
\text { (7). }\end{array}$ & $\begin{array}{l}\text { Govindarajan (1984), Cadez } \\
\text { and Guilding (2008), Hoque } \\
\text { and James (2000), Harrison } \\
\text { (2009), Hoque (2011). }\end{array}$ \\
\hline User satisfaction & $\begin{array}{l}\text { Level of satisfaction or dissatisfaction with the } \\
\text { information provided by MAS on a 7-point scale } \\
\text { that could range from "completely (1) } \\
\text { unsatisfied" to "completely satisfied" (7). }\end{array}$ & $\begin{array}{l}\text { Doll and Torkzadeh (1988), } \\
\text { Fong and Quaddus (2010); } \\
\text { Macinati and Anessi-Pessina, } \\
\text { (2014), Rai et al. (2002). }\end{array}$ \\
\hline User training & $\begin{array}{l}\text { Degree of agreement or disagreement with the } \\
\text { various statements related to training, on a } 7- \\
\text { point scale that could range from "strongly } \\
\text { disagree" (1) to "strongly agree" (7). }\end{array}$ & $\begin{array}{l}\text { Shields (1995), Krumwiede } \\
\text { (1998), Krumwiede et al. (2008). }\end{array}$ \\
\hline $\begin{array}{l}\text { Top management } \\
\text { support }\end{array}$ & $\begin{array}{l}\text { Degree of agreement or disagreement with the } \\
\text { various statements related to the active } \\
\text { support to the MAS, on a 7-point scale that } \\
\text { could range from "strongly disagree" (1) to } \\
\text { "strongly agree" (7). }\end{array}$ & $\begin{array}{l}\text { Shields (1995), (e.g., } \\
\text { Krumwiede, 1998; Krumwiede } \\
\text { et al., 2008; Tontiset and } \\
\text { Ussahawanitchakit, 2010). }\end{array}$ \\
\hline Task uncertainty & $\begin{array}{l}\text { Degree of agreement or disagreement with the } \\
\text { various statements related to task execution, } \\
\text { on a 7-point scale that could range from } \\
\text { "strongly disagree" (1) to "strongly agree" (7). }\end{array}$ & $\begin{array}{l}\text { Withey et al. (1983), Chong, } \\
\text { (2004), Soobaroyen and } \\
\text { Poorundersing (2008). }\end{array}$ \\
\hline $\begin{array}{l}\text { Decentralization of } \\
\text { decisions }\end{array}$ & $\begin{array}{l}\text { Rate the extent of the company's } \\
\text { decentralization on a 7-point scale that could } \\
\text { range from "very low" (1) to "very high"(7). }\end{array}$ & $\begin{array}{l}\text { Gordon and Narayanan (1984), } \\
\text { Abdel-Kader and Luther, (2008, } \\
\text { Soobaroyen and Poorundersing } \\
\text { (2008). }\end{array}$ \\
\hline $\begin{array}{l}\text { Accountant } \\
\text { participation in } \\
\text { strategic decisions }\end{array}$ & $\begin{array}{l}\text { Rate the accountant participation on a 7-point } \\
\text { scale that could range from "very low" (1) to } \\
\text { "very high" (7). }\end{array}$ & $\begin{array}{l}\text { Wooldridge and Floyd (1990), } \\
\text { Cadez and Guilding (2012, } \\
\text { 2008). }\end{array}$ \\
\hline $\begin{array}{l}\text { Competitive } \\
\text { environmental } \\
\text { uncertainty }\end{array}$ & $\begin{array}{l}\text { Rate of the changes on a 7-point scale that } \\
\text { could range from "very slow" (1) to "very fast" } \\
\text { (7). }\end{array}$ & $\begin{array}{l}\text { Miller and Friesen (1983), } \\
\text { Agbejule (2005). }\end{array}$ \\
\hline
\end{tabular}

\footnotetext{
*The authors, presented as sources, used the four dimensions, individually.

** If respondents did not engage in some of the evaluated activities, they had an option to choose "not applicable" for each of the activities.
} 
Table 4 - Validity and reliability of constructs

\begin{tabular}{|c|c|c|c|c|c|c|c|c|c|c|c|c|}
\hline & MAS & DEC & TUN & UTR & USA & CEU & TMS & APD & MAP & ORP & $\alpha$ & $\mathrm{CR}$ \\
\hline MAS - Management accounting system & 0.694 & & & & & & & & & & ---- & 0.899 \\
\hline DEC - Decentralization of decisions & 0.157 & 0.602 & & & & & & & & & 0.880 & 0.882 \\
\hline TUN - Task uncertainty & 0.118 & 0.023 & 0.514 & & & & & & & & 0.752 & 0.759 \\
\hline UTR - User training & 0.160 & 0.104 & 0.085 & 0.863 & & & & & & & 0.949 & 0.950 \\
\hline USA - User Satisfaction & 0.159 & 0.060 & 0.118 & 0.318 & 0.733 & & & & & & 0.913 & 0.916 \\
\hline CEU - Competitive environmental uncertainty & 0.038 & 0.115 & 0.001 & 0.011 & 0.009 & 0.682 & & & & & 0.913 & 0.915 \\
\hline TMS - Top management support & 0.074 & 0.089 & 0.038 & 0.266 & 0.214 & 0.021 & 0.787 & & & & 0.879 & 0.880 \\
\hline APD - Accountant participation in strategic decisions & 0.063 & 0.130 & 0.002 & 0.102 & 0.047 & 0.010 & 0.110 & 0.885 & & & 0.958 & 0.959 \\
\hline MAP - Managerial performance & 0.275 & 0.132 & 0.040 & 0.130 & 0.154 & 0.001 & 0.147 & 0.142 & 0.593 & & 0.915 & 0.921 \\
\hline ORP - Organizational performance & 0.123 & 0.089 & 0.012 & 0.069 & 0.106 & 0.007 & 0.078 & 0.037 & 0.246 & 0.520 & 0.838 & 0.842 \\
\hline
\end{tabular}

Notes: $\alpha$ - Cronbach's Alpha; CR - Composite Reliability; AVE is presented in the main diagonal; below the diagonal is presented the square of the correlations between the constructs 
Table 5 - Results of research hypotheses

\begin{tabular}{|c|c|c|c|c|}
\hline Hypotheses & & & & Supported \\
\hline Top management support & $--->$ & MAS & $\mathrm{H} 1 \mathrm{a}(+)$ & No \\
\hline Top management support & $--->$ & User training & $\mathrm{H} 1 \mathrm{~b}(+)$ & Yes \\
\hline Top management support & $--->$ & User satisfaction & $\mathrm{H} 1 \mathrm{c}(+)$ & Yes \\
\hline User training & $--->$ & MAS & $\mathrm{H} 2 \mathrm{a}(+)$ & Yes \\
\hline User training & $--->$ & User satisfaction & $\mathrm{H} 2 \mathrm{~b}(+)$ & Yes \\
\hline User satisfaction & $--->$ & MAS & $\mathrm{H} 3(+)$ & Yes \\
\hline Task uncertainty & $--->$ & MAS & $\mathrm{H} 4 \mathrm{a}(+)$ & No \\
\hline Task uncertainty & $--->$ & Managerial Performance & H4b (-) & No \\
\hline Decentralization of decisions & $--->$ & MAS & H5a (+) & Yes \\
\hline Decentralization of decisions & $-->$ & Managerial Performance & H5b (+) & Yes \\
\hline Decentralization of decisions & $-->$ & Organizational performance & $\mathrm{H} 5 \mathrm{c}(+)$ & Yes \\
\hline $\begin{array}{l}\text { Accountant participation in strategic } \\
\text { decisions }\end{array}$ & $--->$ & MAS & H6a (+) & No \\
\hline $\begin{array}{l}\text { Accountant participation in strategic } \\
\text { decisions }\end{array}$ & $--->$ & Organizational performance & $\mathrm{H} 6 \mathrm{~b}(+)$ & No \\
\hline Competitive environment uncertainty & $--->$ & Decentralization of decisions & $\mathrm{H} 7 \mathrm{a}(+)$ & Yes \\
\hline Competitive environment uncertainty & $--->$ & MAS & $\mathrm{H} 7 \mathrm{~b}(+)$ & No \\
\hline Competitive environment uncertainty & $--->$ & Managerial Performance & $\mathrm{H} 7 \mathrm{c}(-)$ & Yes \\
\hline Competitive environment uncertainty & $--->$ & Organizational performance & H7d (-) & Yes \\
\hline MAS & $--->$ & Managerial Performance & $\mathrm{H} 8 \mathrm{a}(+)$ & Yes \\
\hline MAS & $-->$ & Organizational performance & $\mathrm{H} 8 \mathrm{~b}(+)$ & No \\
\hline Managerial Performance & $--->$ & Organizational performance & $\mathrm{H} 9(+)$ & Yes \\
\hline
\end{tabular}

Table 6 - Indirect effects related to not-confirmed hypotheses

\begin{tabular}{|l|r|r|r|}
\hline & MAS & $\begin{array}{c}\text { Managerial } \\
\text { performance }\end{array}$ & $\begin{array}{c}\text { Organizational } \\
\text { performance }\end{array}$ \\
\hline MAS & --- & --- & 0.171 \\
\hline Top management support & 0.190 & --- & --- \\
\hline Task uncertainty & --- & -0.098 & --- \\
\hline Competitive environment uncertainty & 0.083 & --- & - \\
\hline
\end{tabular}

